Prepared in cooperation with the U.S. Department of Homeland Security Federal Emergency Management Agency

\title{
Elevation of the March-April 2010 Flood High Water in Selected River Reaches in Rhode Island
}

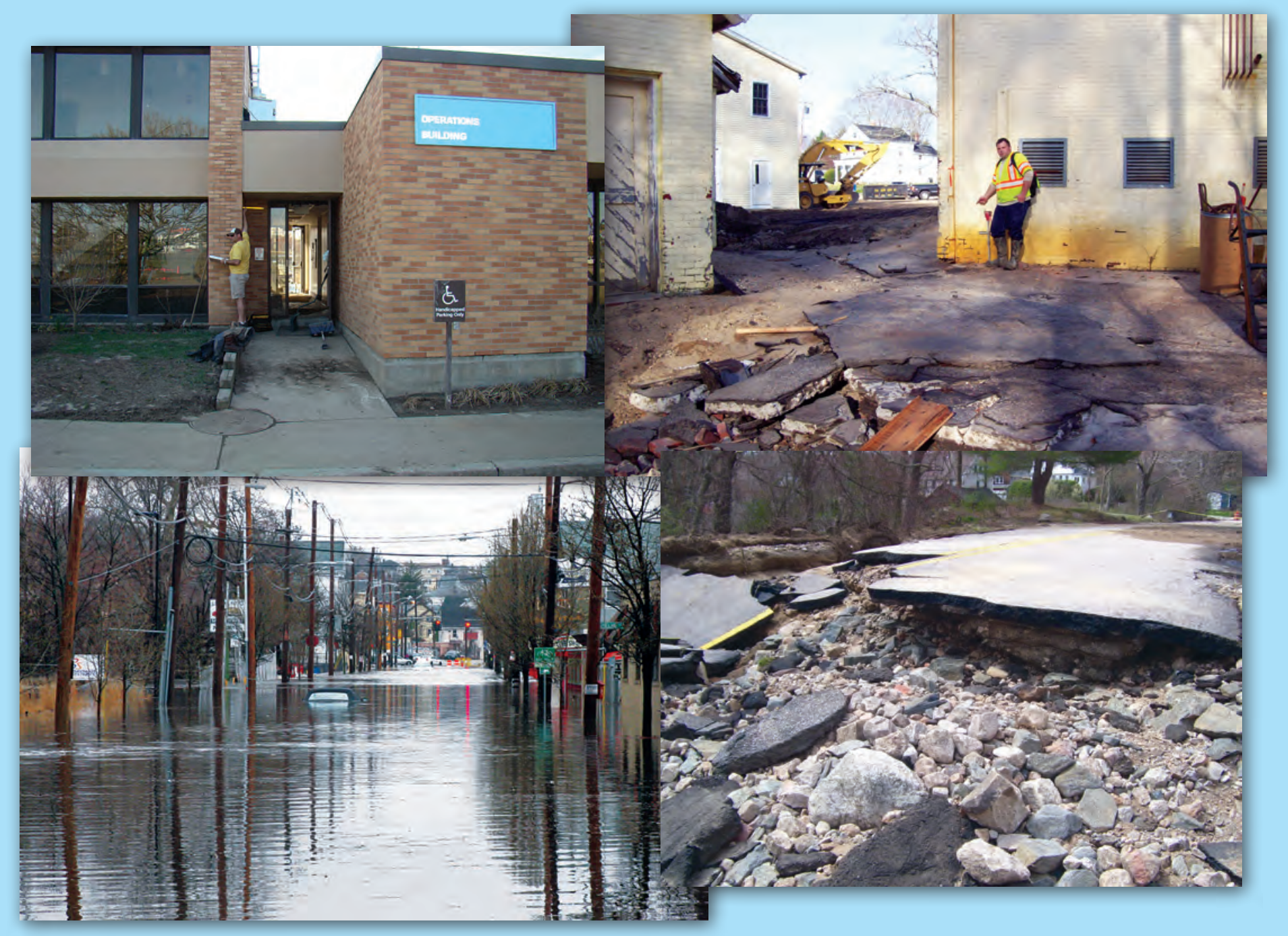

Open-File Report 2011-1029

U.S. Department of the Interior

U.S. Geological Survey 



\section{Elevation of the March-April 2010 Flood High Water in Selected River Reaches in Rhode Island}

By Phillip J. Zarriello and Gardner C. Bent

Prepared in cooperation with the

U.S. Department of Homeland Security

Federal Emergency Management Agency

Open-File Report 2011-1029 


\title{
U.S. Department of the Interior \\ KEN SALAZAR, Secretary \\ U.S. Geological Survey \\ Marcia K. McNutt, Director
}

\author{
U.S. Geological Survey, Reston, Virginia: 2011
}

For more information on the USGS - the Federal source for science about the Earth, its natural and living resources, natural hazards, and the environment, visit http://www.usgs.gov or call 1-888-ASK-USGS

For an overview of USGS information products, including maps, imagery, and publications, visit http://www.usgs.gov/pubprod

To order this and other USGS information products, visit http://store.usgs.gov

Any use of trade, product, or firm names is for descriptive purposes only and does not imply endorsement by the U.S. Government.

Although this report is in the public domain, permission must be secured from the individual copyright owners to reproduce any copyrighted materials contained within this report.

Suggested citation:

Zarriello, P.J., and Bent, G.C., 2011, Elevation of the March-April 2010 flood high water in selected river reaches in Rhode Island: U.S. Geological Survey Open-File Report 2011-1029, 34 p. 


\section{Contents}

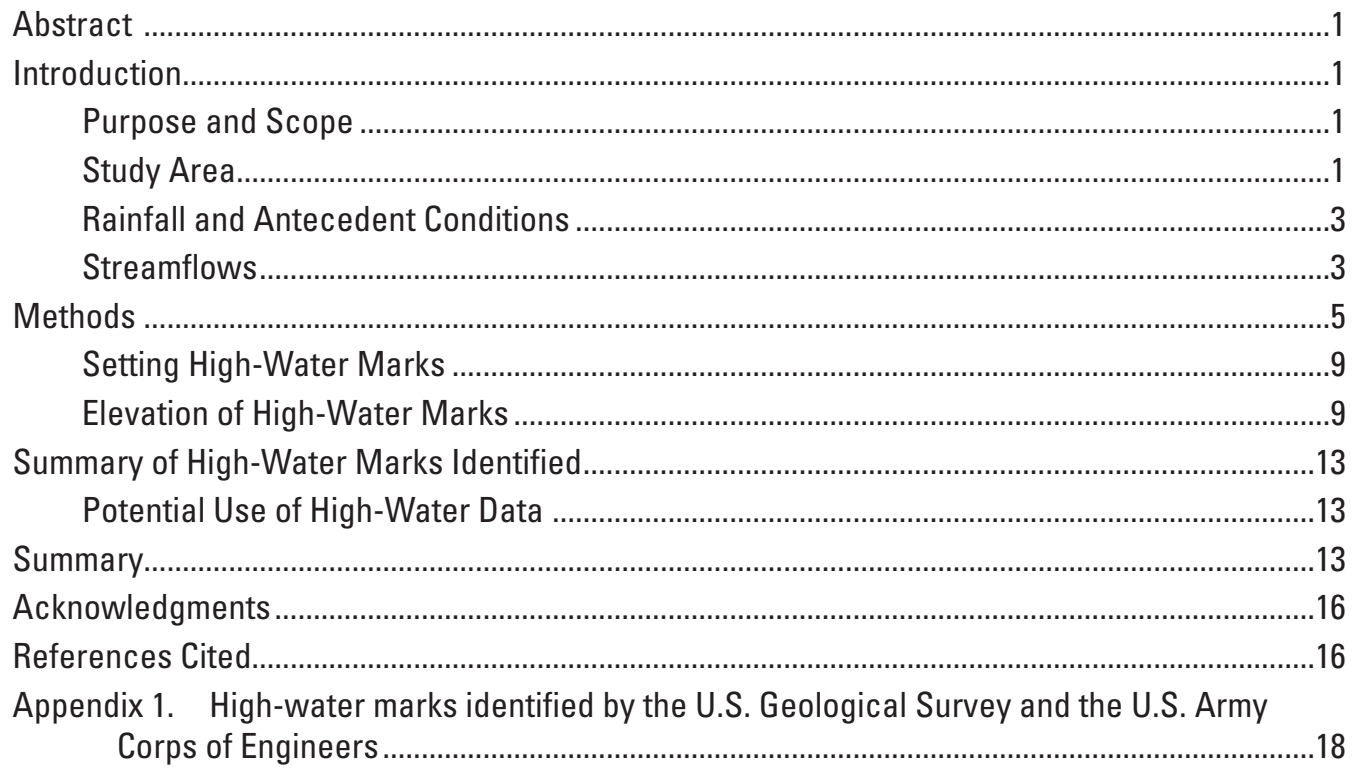

\section{Figures}

1. Map showing river basins where high-water elevations were determined following the March-April 2010 floods in Rhode Island

2. Map showing total rainfall during February and March 2010 in southeastern New England...

3. Graphs showing daily rainfall $(A)$ hyetographs and $(B)$ cumulative totals during February and March 2010 at five National Weather Service stations in Rhode Island

4. Graphs showing period-of-record daily mean flow percentiles and 2010 daily mean flow at $(A)$ Hunt River near East Greenwich (01117000) and $(B)$ Wood River at Hope Valley (01118000), Rhode Island.

5. Photographs showing examples of high-water mark debris lines on trees and structures following the March-April 2010 floods in Rhode Island

6. Map showing fixed-based station Global Positioning System receiver network and National Geodetic Survey bench-mark control points used in the determination of the elevation of the March-April 2010 flood high water in Rhode Island

7. Map showing areas of availability of Llght Detection and Ranging (LIDAR) data and projected 2011 LIDAR data in Rhode Island and adjacent states. 


\section{Tables}

1. Summary of March-April 2010 flood peak stage and flow data at selected U.S. Geological Survey streamgages in Rhode Island and southeastern Massachusetts ......6

2. Summary of Global Positioning System (GPS) measurements made to National Geodetic Survey (NGS) bench marks..

3. Summary of high-water marks (HWMs) established by the U.S. Geological Survey (USGS) and the U.S. Army Corps of Engineers (USACE) following the March-April 2010 floods in Rhode Island

\section{Conversion Factors}

\begin{tabular}{lcl}
\hline \multicolumn{1}{c}{ Multiply } & \multicolumn{1}{c}{ By } & \multicolumn{1}{c}{ To obtain } \\
\hline & \multicolumn{2}{c}{ Length } \\
\hline inch (in.) & 25.4 & millimeter $(\mathrm{mm})$ \\
foot $(\mathrm{ft})$ & 0.3048 & meter $(\mathrm{m})$ \\
mile $(\mathrm{mi})$ & 1.609 & kilometer $(\mathrm{km})$ \\
\hline \multicolumn{2}{c}{ Area } & \\
\hline square mile $\left(\mathrm{mi}^{2}\right)$ & 259.0 & hectare $(\mathrm{ha})$ \\
square mile $\left(\mathrm{mi}^{2}\right)$ & 2.590 & square kilometer $\left(\mathrm{km}^{2}\right)$ \\
\hline & \multicolumn{1}{c}{ Flow rate } & \\
\hline cubic foot per second $\left(\mathrm{ft}^{3} / \mathrm{s}\right)$ & 0.02832 & cubic meter per second $\left(\mathrm{m}^{3} / \mathrm{s}\right)$ \\
\hline
\end{tabular}

Vertical coordinate information is referenced to the North American Vertical Datum of 1988 (NAVD 88).

Horizontal coordinate information is referenced to the North American Datum of 1983 (NAD 83).

Elevation, as used in this report, refers to distance above the vertical datum. 


\title{
Elevation of the March-April 2010 Flood High Water in Selected River Reaches in Rhode Island
}

\author{
By Phillip J. Zarriello and Gardner C. Bent
}

\section{Abstract}

A series of widespread, large, low-pressure systems in southern New England in late February through late March 2010 resulted in record, or near record, rainfall and runoff. The total rainfall in the region during this period ranged from about 19 to 25 inches, which coupled with seasonal low evaporation, resulted in record or near record peak flows at 21 of 25 streamgages in Rhode Island and southeastern Massachusetts. The highest record peaks occurred in late March-early April and generally greatly exceeded the earlier March peaks that were near or exceeded the peak of record for 10 of the 25 streamgages.

Determination of the flood-peak high-water elevation is a critical part of the recovery operations and post-flood analysis for improving future flood-hazard maps and flood-management practices. High-water marks (HWMs) were identified by the U.S. Geological Survey (USGS) from April 2-7, 2010, and by the U.S. Army Corps of Engineers (USACE) from April 3-7, 2010, in five major river basins including the Blackstone, Hunt, Moshassuck, Pawtuxet, and Woonasquatucket along the mainstems and in many tributaries. The USGS identified 276 HWMs at 137 sites. A site may have more than one HWM, typically upstream and downstream of a bridge. The USACE identified 144 HWMs at 127 sites. The HWMs identified by the USGS and USACE covered about 170 river miles, determined from the upstream and downstream HWMs. Elevation of HWMs were later determined to a standard vertical datum (NAVD 88) using the Global Navigation Satellite System and survey-grade Global Positioning System (GPS) receivers along with standard optical surveying equipment.

\section{Introduction}

Flood flows and water levels set, or nearly set, record highs in late March into early April 2010 following repeated storms. In the wake of the severe flooding, a state of emergency was declared in many communities in Rhode Island, and a statewide Presidential Disaster (number 3311) was declared on March 31, 2010. The President's action affected the emergency recovery operations in Bristol, Kent, Newport, Providence, and Washington Counties. No official estimate of the flood damages could be found, but the flood has been characterized as the worst in 200 years and is estimated to have damages in the $\$ 100$ 's of millions of dollars. As part of the recovery operations, the U.S. Department of Homeland Security's Federal Emergency Management Agency (FEMA) required analysis of the flood to assess damages and to prepare for and minimize future flood damages.

Determination of the peak high-water elevation is a critical part of the recovery operations and post-flood analysis. This information also is extremely valuable when defining and understanding flood risks for flood management. The U.S. Geological Survey (USGS) initially entered into an agreement with the U.S. Army Corps of Engineers (USACE) on April 2010 to identify high-water marks (HWMs) in selected river reaches in Rhode Island. A subsequent agreement between FEMA and the USGS was signed in August 2010 to complete the HWM survey work from the March-April 2010 flood and document the work as part of a larger project with FEMA to support flood-mitigation efforts.

\section{Purpose and Scope}

The purpose of this report is to document the elevation of peak high water following the March-April 2010 flood in selected river reaches in Rhode Island. The report describes the climate and flow conditions prior to the flood, recorded peak gage heights and flows at USGS streamgages, methods used to identify high-water marks, and the surveying methods used to obtain a vertical datum of the HWM. The report summarizes the HWM data for selected river reaches and presents data in tables and figures.

\section{Study Area}

High-water elevations from the March-April 2010 flood were obtained in selected river reaches throughout Rhode Island (fig. 1). These include the Blackstone, Branch, Hunt, Moshassuck, Pawtuxet, Pawcatuck, and Woonasquatucket Rivers (basin names shown in fig. 1). HWMs and elevations were also obtained in many main tributaries to these rivers including the including the Beaver, Chipuxet, Wood, and Queen-Usquepaug Rivers in the Pawcatuck River basin, the North and South Branches and Pocasset Rivers in the 


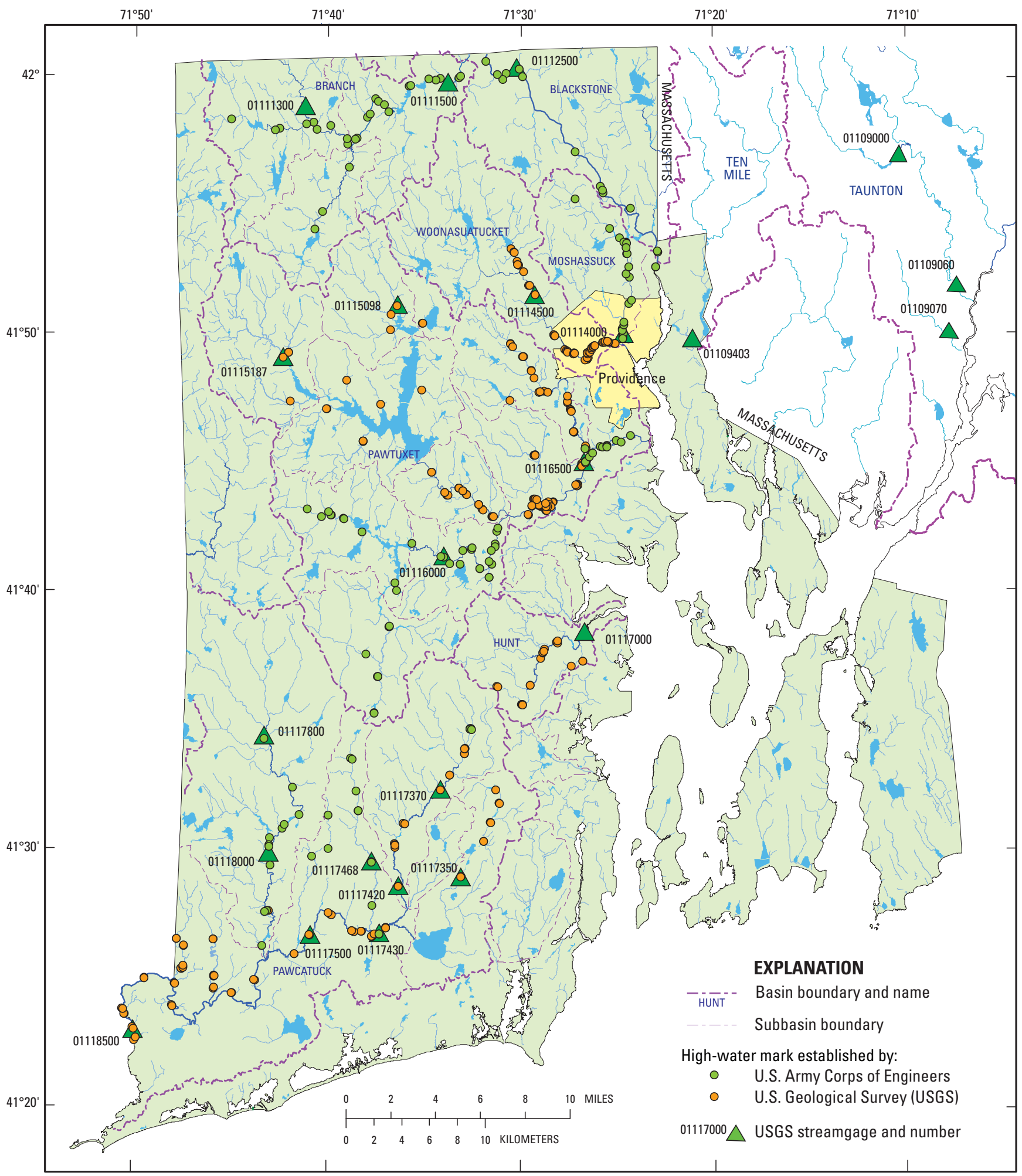

Base from Rhode Island Geographic Information System; State boundary, 1:24,000, 1989; Hydrolines 1,24,000, 1998; Lakes and Ponds, 1:24,000, 1989; Basins, 1:24,000,1990;

Polyconic projection. North American Datum of 1983;

Figure 1. River basins where high-water elevations were determined following the March-April 2010 floods in Rhode Island. Streamgage 01108000 and 01111212 not shown because they are outside the map extent. 
Pawtuxet River Basin, and other smaller tributaries (subbasin boundaries are shown in figure 1, but the names are not for clarity). In general, HWMs were obtained over a large part of Rhode Island, but the greatest concentration of HWMs was obtained in and around the Providence area.

\section{Rainfall and Antecedent Conditions}

A series of widespread, large, low-pressure systems passed through the New England region in late February and in mid- through late March 2010 resulted in record, or near record, amounts of rainfall. The total March 2010 rainfall at Kingston southeast of Providence is the highest monthly recorded (19.37 in) by the National Weather Service (NWS) since 1893 (COOPID-374266, fig. 2). The second highest total monthly rainfall recorded at Kingston (14.35 in.) was in June 1982.

During a period when evaporation losses are normally low, these low-pressure systems maintained wet soil-moisture conditions and filled available surface storages that resulted in record, or near record, floods in southern New England. The Northeast Regional Climate Center (2010) March Climate Summary report described the following conditions: "The mid-March storm hit the region from March 13-15, dropping as much as 9 inches of rain in eastern Massachusetts. As floodwaters began to recede an additional 2 to 5 inches of rain fell on March 22nd and 23rd, followed by 5 to 9 inches of rain on the 29th and 30th."

Rainfall hyetographs and cumulative rainfall (figs. 3A and $3 \mathrm{~B}$ ) for five NWS Rhode Island daily record stations (COOPIDs-374266, 375270, 376698, 377581, and 379423; fig. 2) exemplify the pattern of excessive moisture during late February and March. Prior to the March high water, a late February storm dropped about 5 inches of rain over the region, saturating soils, filling available storage, and elevating streamflows. Thus, conditions were primed for the first runoff response following the 4 to 7 inches of rain that fell between March 13th and 15th. From late February through mid-March total precipitation ranged from about 8 to 12 inches in the study area. As high water began to recede, an additional 2 to 5 inches of rain fell on March 22-23, which maintained wet conditions and again elevated streamflows in the region. Wet conditions continued through late March with another storm that brought the largest pulse of rain of about 7 to 9 inches on the 29th and 30th. The additional rain resulted in peak stream stages and flows that generally greatly exceeded the earlier March stages and flows.

Overall, the total rainfall at the five NWS stations (fig. 3) from late February through March ranged from about 19 to 25 inches, which is unprecedented in the past 100 -year weather history, especially during the cool season when moisture losses to evaporation are low. Rainfall during this period represents about half the total annual precipitation, which is relatively evenly distributed throughout the year. The total rainfall during February and March 2010 in southeastern
New England (fig. 2) indicates the highest amounts occurred from southeastern Connecticut and southern Rhode Island northward along the southern New England coast. The area of high rainfall in northeastern Massachusetts and northward was about equal to the total rainfall in southeastern Massachusetts and Rhode Island, but flooding was less severe in northeastern Massachusetts because a greater portion of the total rainfall in this region occurred in late February when water storage was more available.

\section{Streamflows}

Peak stages and flows recorded at USGS streamgages in Rhode Island and southeastern Massachusetts (table 1) indicate the magnitude of the March-April 2010 flood relative to the magnitude of past floods over the period of the streamgage record. The 2010 stage and flow data are provisional until the entire segment of streamflow record is analyzed and approved. Waiting for the approval of the 2010 streamflow data would cause undue delays for this report. Approval of the data was not considered necessary for the primary objective of documenting the elevation of the flood high water. However, the data on peak stage and flow were reviewed and are considered to be in good condition for use in this report.

Of the 25 streamgages listed in table 1, the MarchApril 2010 flood set new peak stage and flow records at all streamgages except Wading River near Norton, MA (01109000), which was within about 10 percent of the peak record, and the Blackstone River Basin streamgages (01111300, 01111500, 01112500) with the exception of the relatively new streamgage on the Blackstone River near Uxbridge, MA (01111212). The flood peak occurred at the end of March or the beginning of April for all streamgages listed in table 1. The increase in peak flows from the previous peak of record at the streamgages (excluding Wading River and the Blackstone River Basin streamgages) ranged from about 2 to 275 percent with median increase of 88 percent. The streamgage records indicate that the largest increase in the record peak flow was in the upper Pawcatuck River Basin, including the Wood River Basin and neighboring basins to the north and east, including the Hunt River Basin, the mainstem of the Pawtuxet River, and the South Branch of the Pawtuxet River (fig. 1).

The mid-March peak and the peak around March 24-25 would have been annual peak had more rainfall not occurred. At five streamgages these peaks exceeded the previous peak of record $(01117430,01117800,01115098,01116000$, and 01108000; table 1) and were within about 20 percent of the peak of record at five other streamgages $(01117420,01117468$, 01118000,01115187 , and 01116500 ; table 1). The magnitude of these secondary peaks and the duration of high water reflect the severity of the flood conditions in the area. Unlike HWMs identified in many river reaches in central and eastern Massachusetts that were confounded by mid-March peaks that equaled or exceeded the late March-early April peaks 


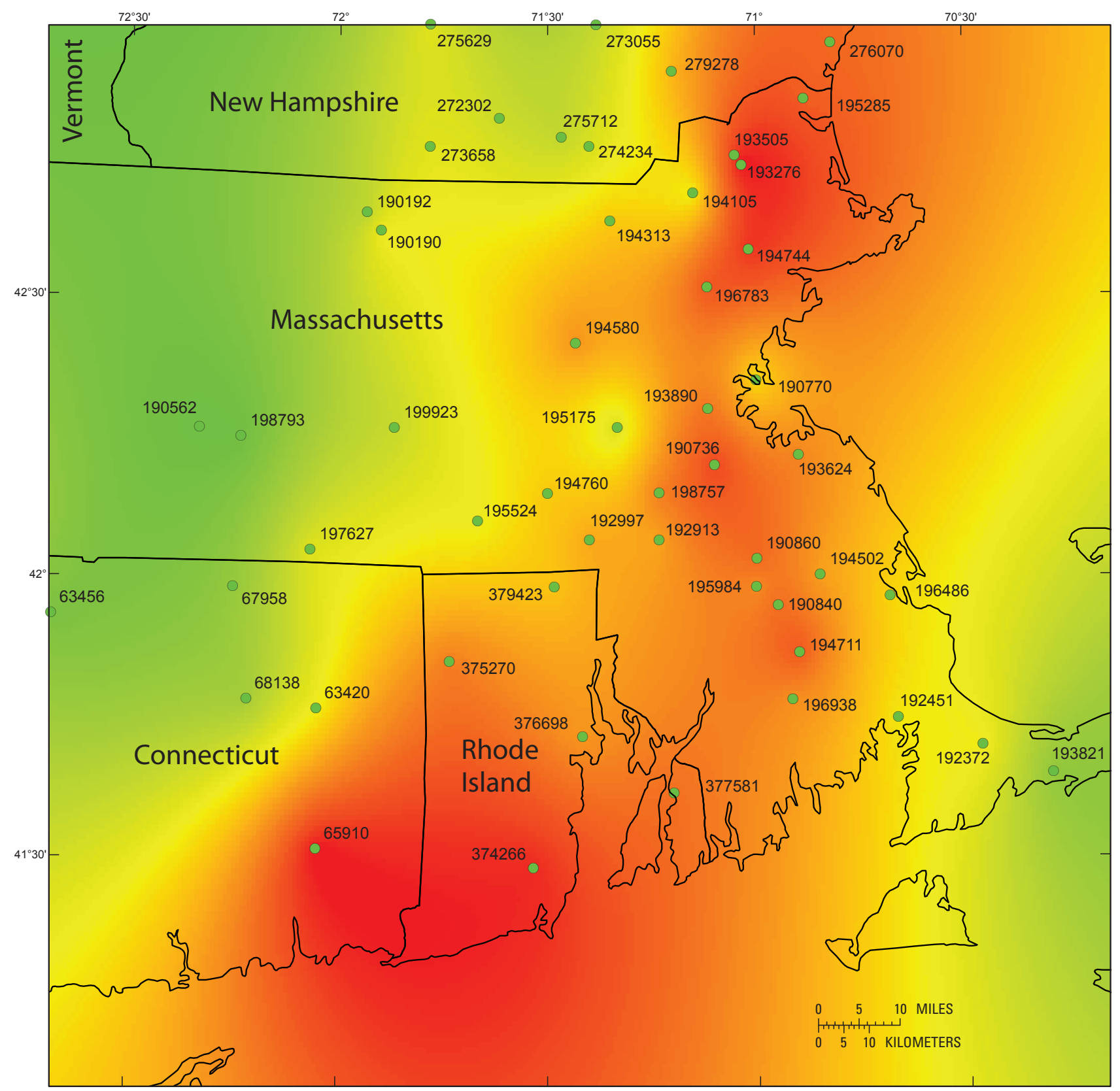

\section{EXPLANATION}

Precipitation, in inches

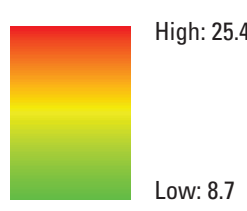

$376698^{\circ} \quad$ National Weather Service Station

Total rainfall map created by linear radial interpolation with constant trending of point data from National Weather Service stations. Note some of the stations used are outside the map extent.

Figure 2. Total rainfall during February and March 2010 in southeastern New England. 


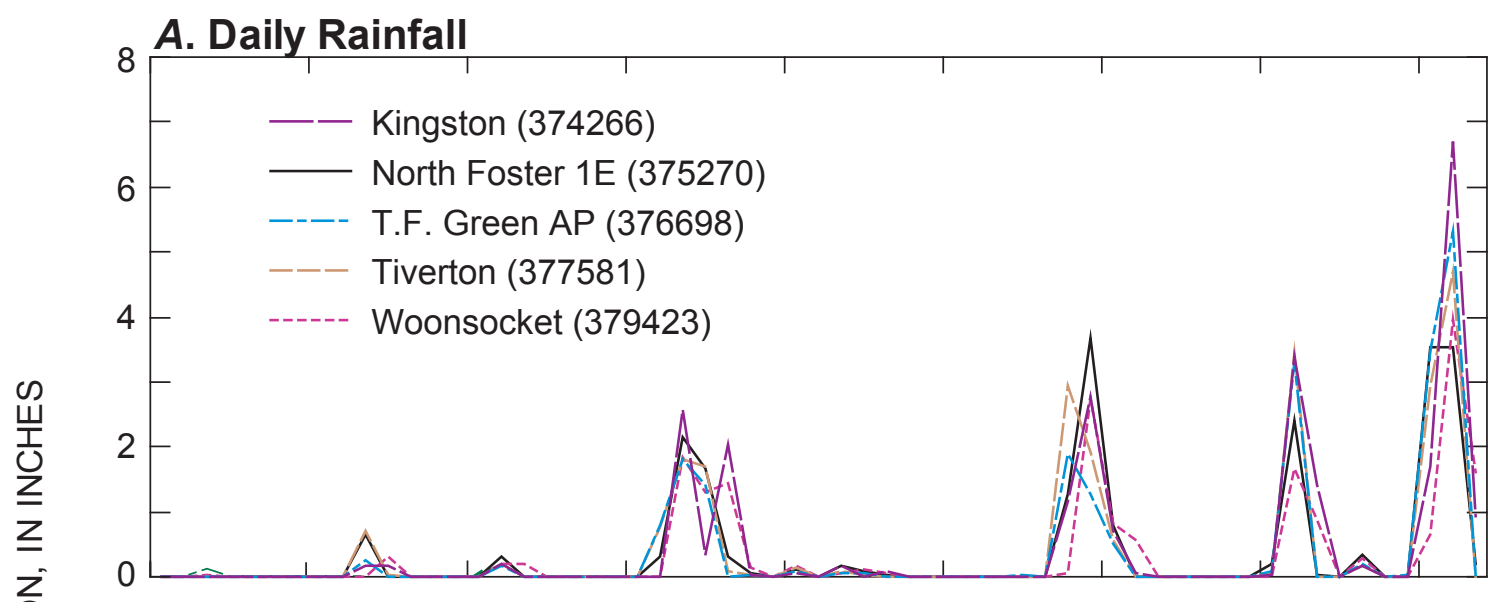

\section{B. Cumulative Daily Rainfall}

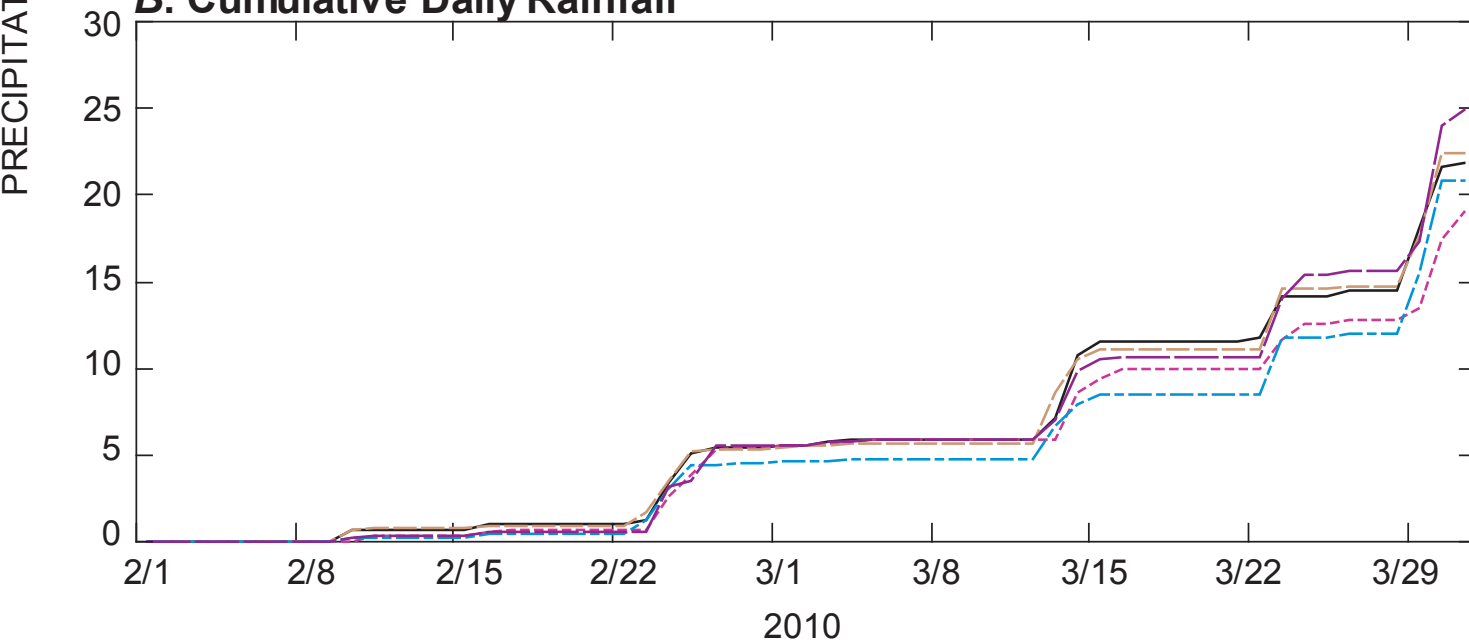

Figure 3. Daily rainfall $(A)$ hyetographs and $(B)$ cumulative totals during February and March 2010 at five National Weather Service stations (NWS) in Rhode Island. Number in parenthesis is the NWS COOPID shown in figure 2.

(Zarriello and Bent, 2010), the HWMs in Rhode Island are distinctly identified by late March-early April peak that greatly exceeded the earlier peaks.

Flow conditions in the region prior to the March floods are illustrated by the daily mean flow for the 2010 water year in relation to the 10th-, 25th-, 50th-, 75th-, and 90thpercentile flows for a given day, calculated from the periodof-record daily mean flows at Hunt River near East Greenwich (01117000) and Wood River at Hope Valley (01118000) (fig. 4A and 4B, respectively). Note that these streamgages were established in 1939 and 1940, respectively. Prior to the late February rainfall, flows were below the median (50th percentile) but quickly rose well above the 90th percentile following the late February rainfall. Flows that exceeded the 90th percentile occurred only 10 percent of the time at this time of year, which is the normal seasonal high-flow period. Flows receded to about the median range in early March, then rose sharply following the mid-March rains and again following the mid-late March rains that set a new peak flow for water year
2010. Flows continued to stay above the 90 th percentile in late March because of saturated conditions and additional rainfall. Another large rainfall event at the end of March caused a rise in streamflow that exceeded earlier peaks and set new period of record peaks at most streamgages in Rhode Island.

\section{Methods}

HWMs are the evidence of the highest water levels during a flood (Benson and Dalrymple, 1967). There are many types of HWMs, but most are left by vegetative debris stranded at the highest water elevation. The best HWMs are small seeds or floating debris that adhere to smooth surfaces or lodge in tree bark that forms a distinct water line. Stain lines on buildings, fences, and other structures also provide excellent marks. HWMs are best identified immediately following the peak stage as time and weather (wind and rain) fade the 


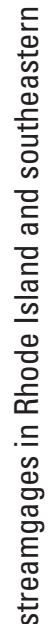

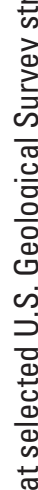

要$$
\text { (1) }
$$

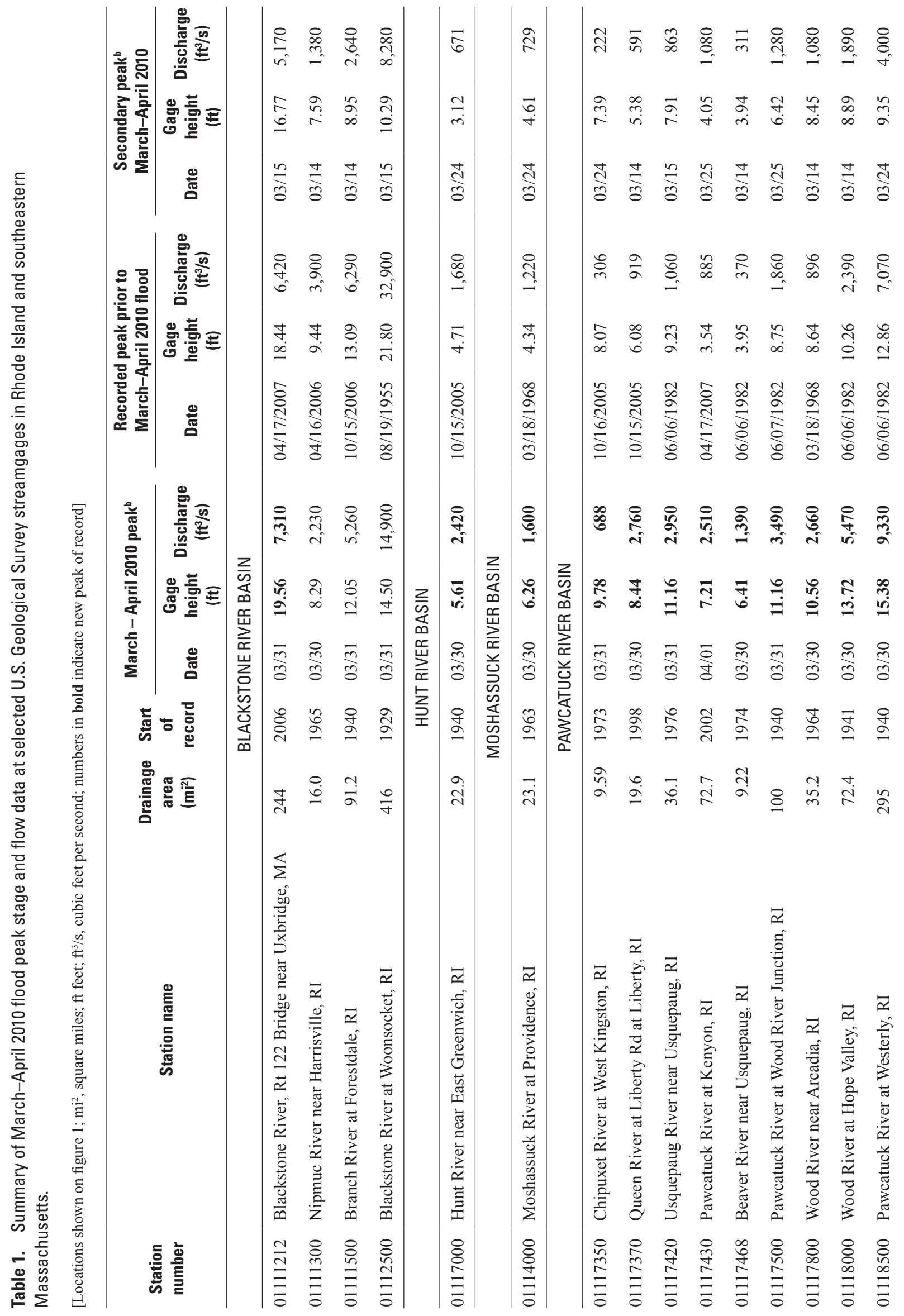




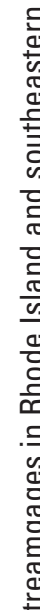$$
\text { 告 }
$$

造

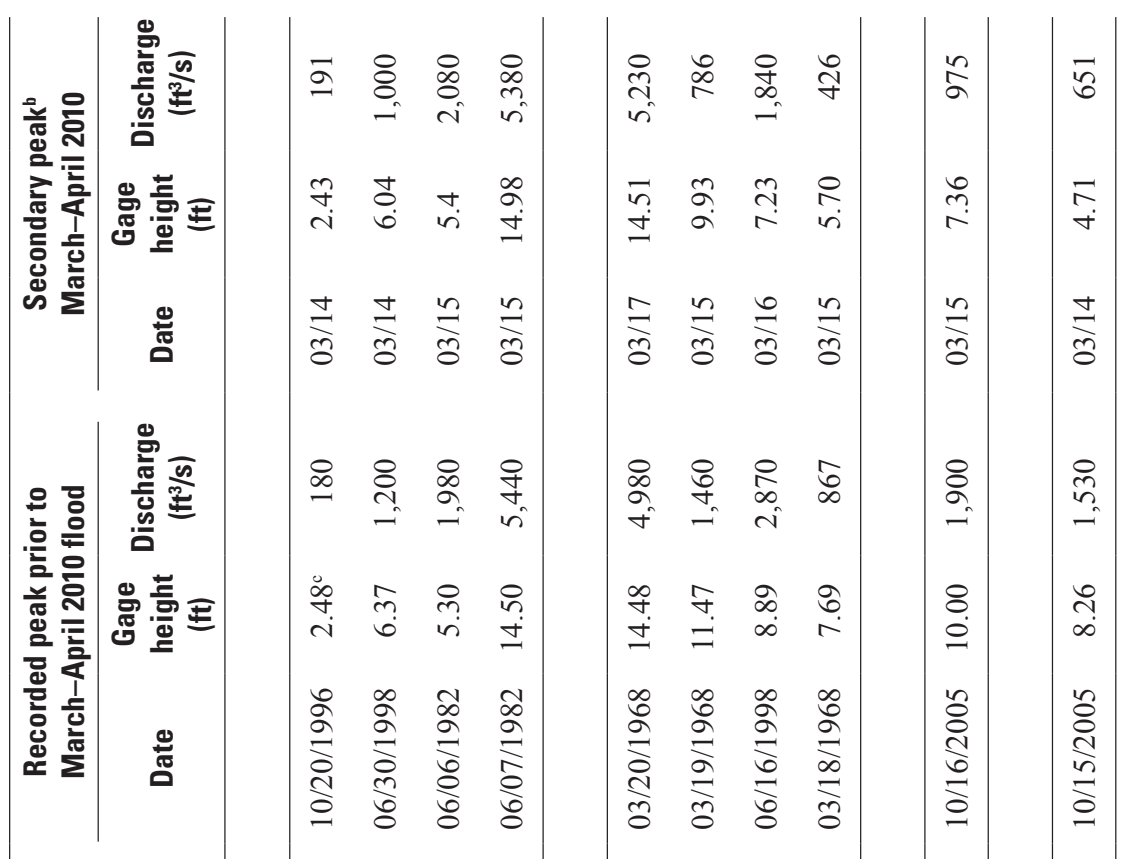

훙

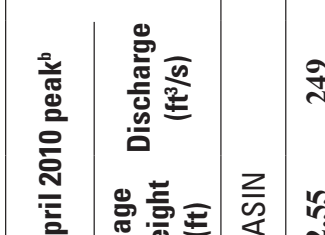

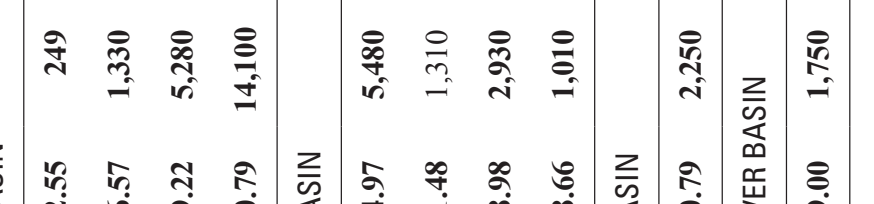

ত্]

흠 离

心.

.

$\frac{\pi}{\pi}$

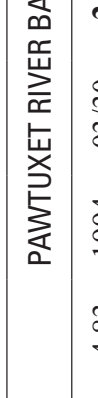

$$
\begin{aligned}
& 5 \\
& 0 \\
& 0 \\
& 0 \\
& 0 \\
& 0 \\
& 0 \\
& 0 \\
& 0 \\
& 0 \\
& 0
\end{aligned}
$$

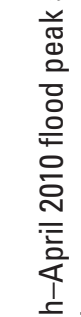

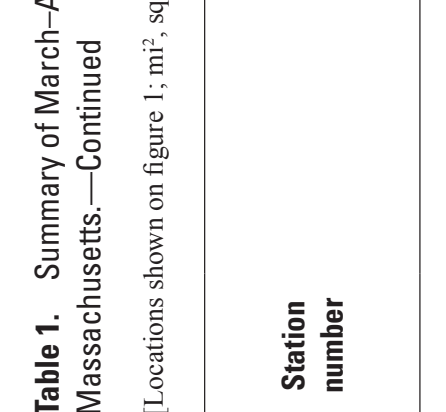




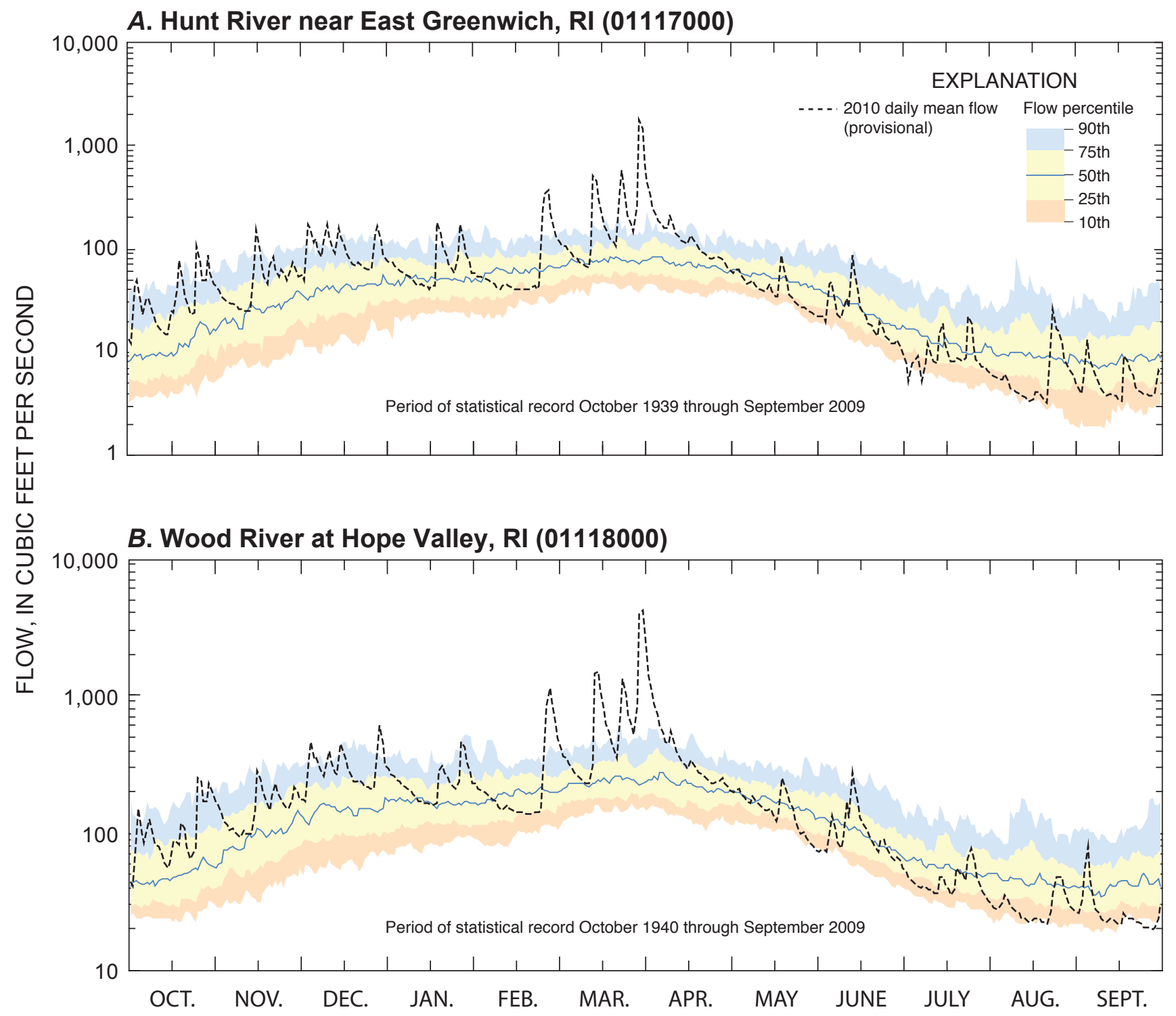

Figure 4. Period-of-record daily mean flow percentiles and 2010 daily mean flow at $(A)$ Hunt River near East Greenwich (01117000) and $(B)$ Wood River at Hope Valley (01118000), Rhode Island. Location shown in figure 1. 
evidence of the peak-water line. Additionally, care was taken to identify HWMs farthest from the main channel as possible where velocities are generally small and pileup or drawdown's common in fast moving waters are best avoided. The general methods used to identify and document HWMs are described by Benson and Dalrymple (1967).

\section{Setting High-Water Marks}

USGS field crews consisted of at least one person experienced in identifying HWMs. Crews would identify HWMs and corroborating evidence of surrounding HWMs. The corroborating information became more important as the quality of the HWM decreased. After a satisfactory HWM was found, a more permanent identification mark was established, such as a disk, stake, chisel mark, pen line or paint line (examples shown in fig. 5). Flagging, written descriptions, sketches, photos, and handheld Geographic Position System (GPS) horizontal position measurements were made so the marks could be found later and surveyed to a standard vertical datum or for other analysis, such as determination of the flood profile over the river reach.

Identification of HWMs by the USGS began on April 2 and continued through April 7, 2010, by up to six field crews on a given day. Most of the HWMs were determined from April 5-7, when five or six crews were deployed. In the first 2 days, April 2-3, only one and two crews were deployed, respectively, because of outstanding streamgaging activities related to the flood. The HWMs generally were of good quality because they were obtained soon after the flood peak. Dates and other supporting information on HWMs obtained by the USACE were not noted in the summary spreadsheet or in limited field notes supplied by the USACE. Christopher Hatfield (USACE, oral commun., 2011) indicated the USACE HWMs were obtained from April 3-7.

\section{Elevation of High-Water Marks}

Elevation of HWMs were later surveyed to a standard vertical datum (NAVD 88) using the Global Navigation Satellite System (GNSS) and survey-grade GPS receivers along with standard optical-surveying equipment. The GPS surveys were conducted using four Trimble $\mathrm{R} 8$ receivers that support the L1 and L2 signals; two of the receivers also support GLONASS L2C and L5 signals. At each HWM site a temporary survey point (PK) was established in an open area to provide the best possible satellite reception. For each PK, the GPS receiver was initialized away from the PK and then positioned over the PK. This procedure was repeated by reinitializing the GPS unit (flipping the unit upside down for several seconds to lose the GPS signals) to obtain an independent reading. If the vertical elevation of the PK differed by more than about $0.10 \mathrm{ft}$, the procedure was repeated until an acceptable agreement was reached. Elevation of repeated PK measurements generally agreed to within $0.05 \mathrm{ft}$. Standard optical surveying equipment was then used to tie the HWM to the PK elevation using a closed-loop survey. Ninety-eight percent of the 291 loop surveys closed to within $0.01 \mathrm{ft}$ or less, 2 percent closed to within $0.02 \mathrm{ft}$.

Continuous real-time differential corrections to the GPS horizontal and vertical positions were made using a proprietary fixed-base station GPS network operated by KeyNetGPS, Inc. The network and associated software determine corrections for satellite signals received by the field GPS receiver for ionosphere and other atmospheric disturbances recorded at three or more of the closest fixed-base stations relative to the position of the field GPS receiver. The fixed-base stations receivers continuously stream data to a central server that calculates corrections at the location of the field GPS receiver in real time. The Trimble GPS field controllers require version 12 controller software to utilize the fixed network. The fixed-station network in the Rhode Island region, nearest the HWMs, consists of five stations (fig. 6)-Providence, RI (NBC1), Fall River (ABL1), Framingham (KP16), Boston (KP19), MA, and Norwich, CT (MTG1). Quality-assurance GPS measurements were made at 29 National Geodetic Survey (NGS) bench marks (BMs) with vertical datum throughout the study area (fig. 6). The elevation of the GPS measured BMs yielded a vertical root mean square error (RMSE) of $0.09 \mathrm{ft}$ (table 2). The accuracy of the HWM survey meets the standards specified by FEMA (2003) in Guidelines and specifications for flood hazards mapping partners, Appendix A: Guidance for aerial mapping and surveying.

Elevations of 87 USGS HWMs were initially surveyed with a Leica system 1200 (GX1220) GPS that uses a temporary GPS base station to make baseline corrections for atmospheric and ionosphere disturbances to the rover GPS unit. Most of these HWM elevations (75) were resurveyed with the Trimble GPS with the exception of $6 \mathrm{HWMs}$ that were found destroyed and 6 that had been surveyed during the initial HWM work and would likely be difficult to find because of limited field notes. The Leica GPS survey work was redone to the extent possible because check measurements with the Trimble GPS yielded inconsistent results. Of the 75 HWMs that were surveyed using the Leica and Trimble GPS systems, the elevation of HWMs determined with the Leica GPS had a mean and median difference of $-0.11 \mathrm{ft}$ and ranged from 0.20 to $-0.68 \mathrm{ft}$ different from the elevation determined with the Trimble GPS. The elevations determined using the Trimble GPS survey are reported, where possible, because more ground-truth information was obtained, and the atmospheric and ionosphere corrections were considered more accurate.

The USACE surveyed 41 out of the 144 HWMs identified as part of their initial effort to identify high-water levels. The HWMs surveyed by USACE used survey-grade Leica GPS equipment that uses a temporary base GPS station and a rover GPS unit to make baseline corrections for atmospheric and ionosphere disturbances. The control information appears to be limited to two NGS bench marks. The HWMs were not resurveyed by the USGS because of difficulty finding USACE HWMs, which were generally limited to horizontal position coordinates. 


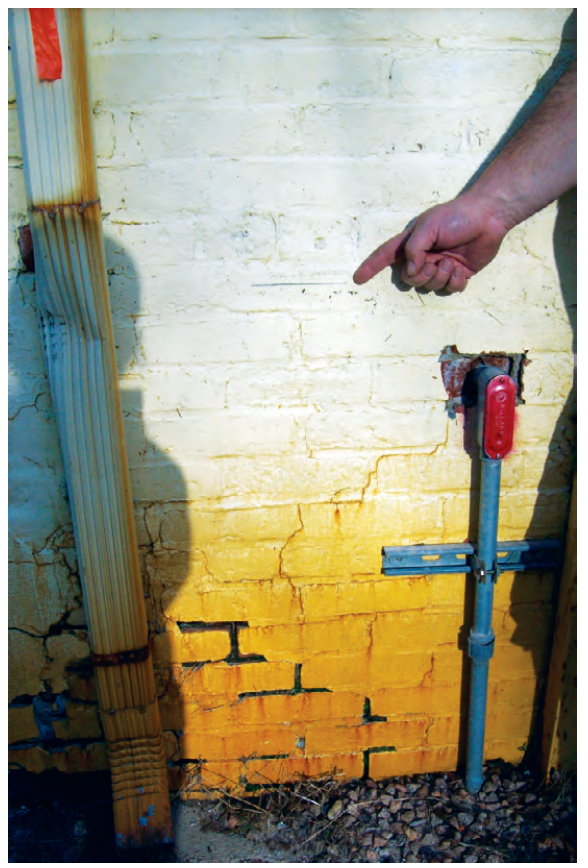

Ashaway River (Ash-20.1)

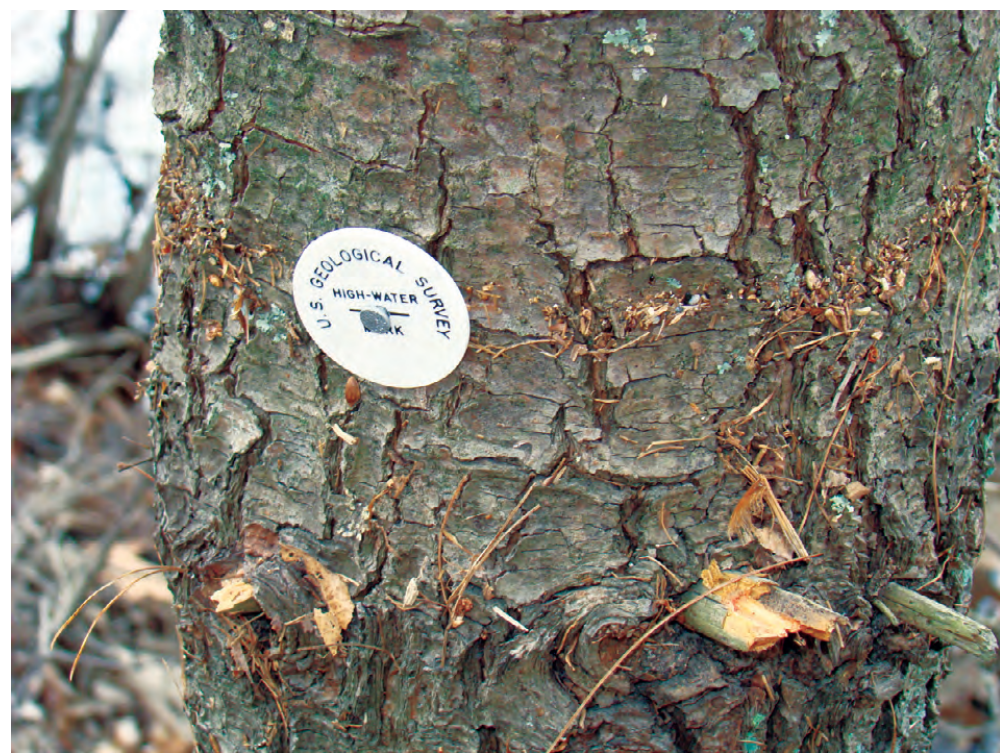

Pawcatuck River (500904)

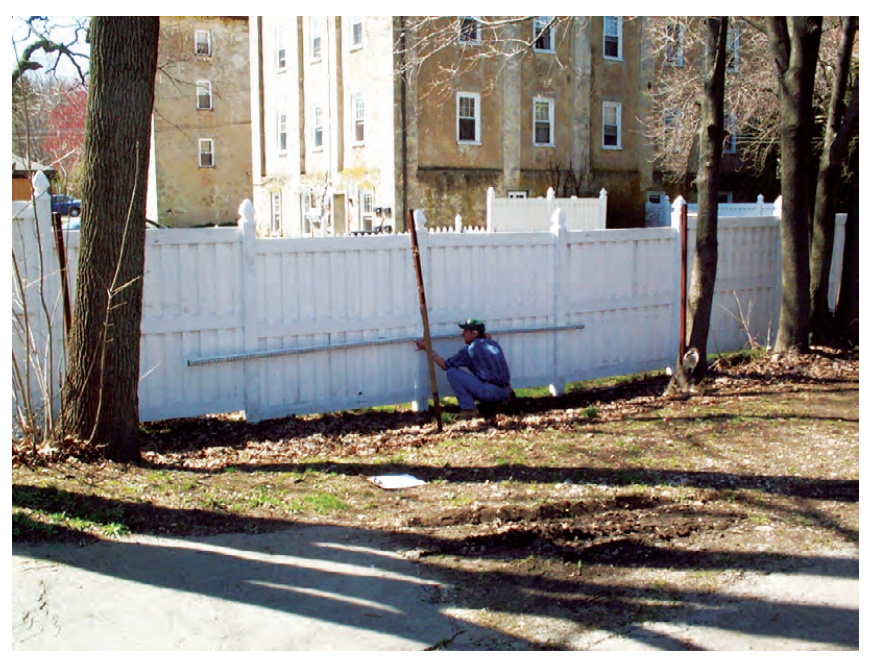

Woonasquatucket River (WR-2-2.1)

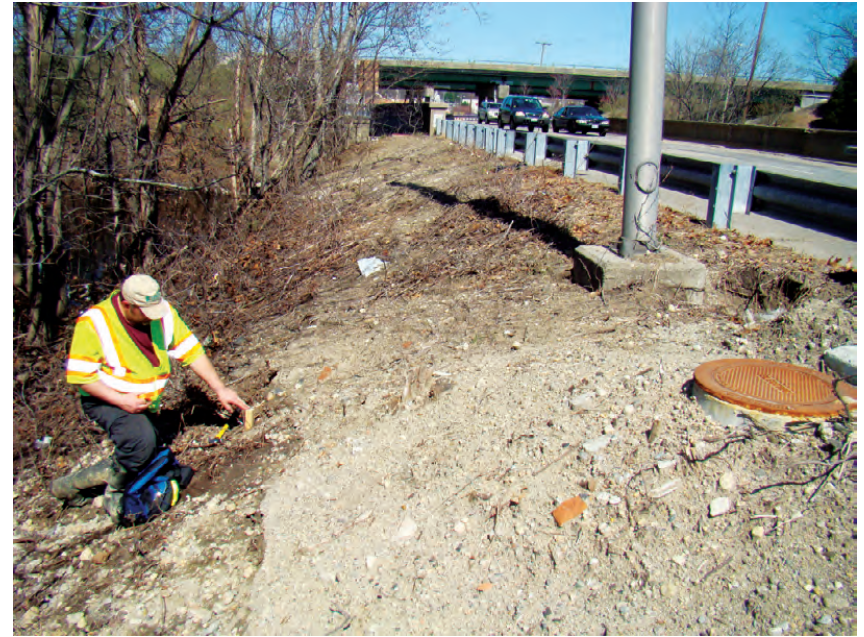

Pawtuxet River (500310)

Figure 5. Examples of high-water mark debris lines on trees and structures following the March-April 2010 floods in Rhode Island. Value in parentheses refers to the HWM_ID in appendix table 1-1. 


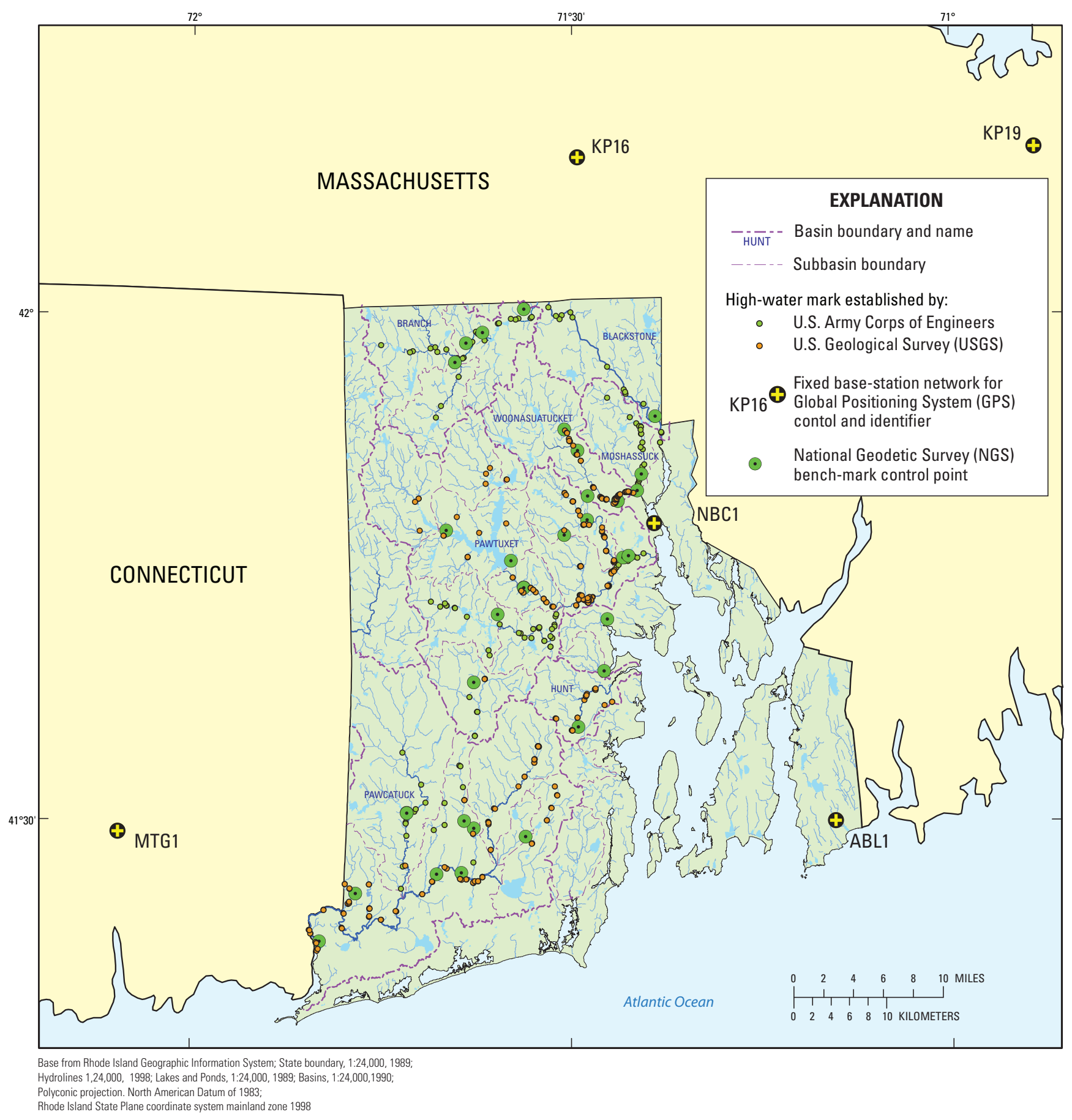

Figure 6. Fixed-based station Global Positioning System receiver network and National Geodetic Survey bench-mark control points used in the determination of the elevation of the March-April 2010 flood high water in Rhode Island. 
Table 2. Summary of Global Positioning System (GPS) measurements made to National Geodetic Survey (NGS) bench marks.

[PID, NGS identification; EAST and NORTH, horizontal position referenced to North American Datum of 1983 (NAD 83), in feet; ELEV(88), vertical reference to North American Datum of 1988 (NAVD 88), in feet; OFFSET, GPS point offset from bench mark to obtain the best quality signal; DELTAS, difference between published and surveyed values, in feet; -, not determined; RMSE, Root Mean Square Error, in feet]

\begin{tabular}{|c|c|c|c|c|c|c|c|c|c|c|}
\hline \multirow{2}{*}{ PID } & \multicolumn{3}{|c|}{ Published by NGS } & \multicolumn{3}{|c|}{ Surveyed by GPS } & \multirow{2}{*}{$\begin{array}{c}\text { OFFSET } \\
\text { (feet) }\end{array}$} & \multicolumn{3}{|c|}{ Deltas } \\
\hline & EAST & NORTH & ELEV(88) & EAST & NORTH & ELEV(88) & & EAST & NORTH & $\operatorname{ELEV(88)}$ \\
\hline LW1207 & $290,212.264$ & $323,557.039$ & 445.08 & $290,212.437$ & $323,557.217$ & 445.140 & 0.00 & 0.17 & 0.18 & 0.06 \\
\hline MY6203 & $310,892.869$ & $335,656.078$ & 243.29 & $310,882.757$ & $335,646.307$ & 241.788 & 1.63 & - & - & 0.13 \\
\hline LW1892 & $292,989.929$ & $201,602.231$ & 434.8 & $292,989.792$ & $201,602.270$ & 434.671 & 0.00 & -0.14 & 0.04 & -0.13 \\
\hline LW1141 & - & - & 83.45 & $268,925.367$ & $154,707.535$ & 83.590 & 0.00 & - & - & 0.14 \\
\hline LW0771 & - & - & 55.49 & $279,430.066$ & $132,676.297$ & 55.790 & -0.36 & - & - & -0.06 \\
\hline LW1347 & - & - & 202.54 & $310,850.487$ & $235,538.720$ & 200.180 & 2.26 & - & - & -0.10 \\
\hline LW1453 & - & - & 314.4 & $282,621.512$ & $256,357.091$ & 321.464 & -7.15 & - & - & -0.09 \\
\hline LW0111 & - & - & 32.60 & $339,853.707$ & $205,684.041$ & 32.539 & 0.00 & - & - & -0.06 \\
\hline LW1641 & - & - & 36.51 & $346,542.753$ & $246,432.034$ & 36.418 & 0.00 & - & - & -0.09 \\
\hline LW0316 & - & - & 64.77 & $358,095.657$ & $297,277.180$ & 64.631 & 0.00 & - & - & -0.14 \\
\hline LW0949 & - & - & 79.68 & $250,252.691$ & $125,495.235$ & 76.660 & 3.00 & - & - & -0.02 \\
\hline LW0163 & - & - & 23.35 & $351,839.553$ & $270,472.909$ & 20.368 & 2.90 & - & - & -0.09 \\
\hline LW1424 & - & - & 289.10 & $301,519.936$ & $225,959.068$ & 289.159 & 0.00 & - & - & 0.06 \\
\hline LW0750 & - & - & 19.77 & $237,223.597$ & $108,644.453$ & 15.264 & 4.52 & - & - & 0.01 \\
\hline LW1022 & - & - & 136.89 & $311,742.468$ & $146,171.612$ & 136.960 & 0.00 & - & - & 0.07 \\
\hline LW0121 & - & - & 23.04 & $341,073.675$ & $224,402.591$ & 25.781 & -2.82 & - & - & -0.08 \\
\hline LW1204 & - & - & 415.63 & $286,033.511$ & $316,574.751$ & 414.916 & 0.73 & - & - & 0.02 \\
\hline LW0445 & - & - & 211.42 & $333,815.001$ & $268,562.117$ & 211.436 & 0.00 & - & - & 0.02 \\
\hline LW1464 & - & - & 201.31 & $325,530.807$ & $292,335.225$ & 193.683 & 7.51 & - & - & -0.12 \\
\hline LW0165 & - & - & 41.17 & $353,039.393$ & $276,507.026$ & 38.895 & 2.17 & - & - & -0.11 \\
\hline LW1027 & - & - & 117.63 & $293,017.509$ & $149,091.060$ & 117.652 & 0.00 & - & - & 0.02 \\
\hline LW0410 & - & - & 112.84 & $330,259.121$ & $284,989.079$ & 112.425 & 0.32 & - & - & -0.09 \\
\hline LW0085 & - & - & 80.24 & $330,604.679$ & $185,688.068$ & 80.192 & 0.00 & - & - & -0.05 \\
\hline LW1029 & - & - & 173.96 & $289,483.622$ & $151,846.597$ & 173.834 & 0.00 & - & - & -0.13 \\
\hline LW0440 & - & - & 53.08 & $344,755.447$ & $266,854.500$ & 53.092 & 0.00 & - & - & 0.01 \\
\hline LW1211 & - & - & 301.69 & $295,992.778$ & $327,273.661$ & 301.751 & 0.00 & - & - & 0.06 \\
\hline LW1435 & - & - & 302.35 & $306,323.441$ & $245,229.788$ & 299.566 & 2.83 & - & - & 0.05 \\
\hline LW0774 & - & - & 66.03 & $288,483.352$ & $132,983.684$ & 63.207 & 2.67 & - & - & -0.15 \\
\hline \multirow[t]{2}{*}{ LW1430 } & - & - & 328.95 & $325,556.259$ & $254,358.123$ & 320.180 & 8.81 & - & - & 0.04 \\
\hline & & & & & & & & & RMSE & 0.09 \\
\hline
\end{tabular}




\section{Summary of High-Water Marks Identified}

High-water marks were identified along five major river corridors including the Blackstone, Hunt, Moshassuck, Pawtuxet, and Woonasquatucket Rivers and in many tributaries to these rivers by the USGS and the USACE following the March-April 2010 flood (fig. 1; table 3). The USGS identified 276 HWMs at 137 sites (a site may have more than one HWM, typically a bridge crossing with HWMs identified on the upstream and downstream sides from the bridge), which are listed in the appendix table 1-1. Field notes indicate some sites were visited, but no suitable HWM could be found; these sites were not tracked and were not entered into the spreadsheet. Of the 276 HMWs, 6 were found destroyed and no elevation could be obtained. Another six HWMs were also found destroyed during the later GPS survey but had been previously surveyed (USGS-73, USGS-74, USGS-111, USGS119a, USGS-132, USGS-168). The previously surveyed elevations are reported in table 1-1. Six HWMs identified along the Pocasset River (USGS-182a through USGS-182f) during the initial GPS survey were not resurveyed but are reported in table 1-1. One HWM (USGS-21) was not found during the GPS survey but is reported in table 1-1 without an elevation. In total, of the 276 HWMs identified by the USGS, the elevation is reported for $269 \mathrm{HWMs}$.

The USACE identified 144 HWMs at 127 sites, which are listed in the appendix, table 1-2. Note the number of sites was determined from horizontal position information because the descriptive information was limited and the number of sites could be more or less than estimated. Forty-three of the 144 HWMs were previously surveyed by the USACE and were not resurveyed by the USGS. Seventeen of the 144 HWMs were not found and 9 were destroyed; 75 HWMs were surveyed by the USGS. In total, of the 144 HWMs identified by the USACE, the elevation is reported for $118 \mathrm{HWMs}$.

The HWMs identified by the USGS and USACE covered about 170 river miles, as determined from the upstream and downstream HWMs along river reaches, which is about equally divided by river miles covered by USGS and USACE, respectively. The density of HWMs per mile of river reach for USGS HWMs ranges from a lower quartile of about 2.0 to an upper quartile of about 4.2, with a median of about 3.0 HWMs per mile. The density of USACE HWMs ranged from a lower quartile of about 1.0 to an upper quartile of about 2.0, with a median of 1.5 HWMs per mile.

The elevation of USGS HWMs upstream from bridges at 65 locations were, on average, about $1.9 \mathrm{ft}$ higher than the downstream HWMs near the same bridge; near 8 bridges, HWMs at the upstream elevation were lower than the downstream elevation (these sites were not included in the average elevation difference between upstream and downstream HWMs). HWMs higher at the downstream side than upstream side were attributed to the quality of the water mark, which is often reflected in the rating of the HWM for marks identified by USGS.

\section{Potential Use of High-Water Data}

HWMs provide critical information on inundation following a flood. Mapping flood inundation is greatly enhanced by the availability of LIDAR (LIght Detection and Ranging) elevation data, which provides a high level of precision and accuracy (Gesch, 2009). As part of the American Recovery and Reinvestment Act of 2009, a comprehensive LIDAR mapping program was begun in the summer of 2010 to map the coastal northeast (fig. 7) at a 2-meter resolution and a vertical accuracy of $15 \mathrm{~cm}$ (Smith and others, 2010). The LIDAR data generated by this program are not expected to be completed until the fall of 2011. When the LIDAR data become available, the HWM elevations determined in this study can be used to define the extent and depth of flooding in the selected reaches. The new LIDAR data are expected to provide complete coverage of Rhode Island.

\section{Summary}

A series of widespread, large, low-pressure systems in southern New England in late February and in mid- through late March resulted in record, or near record, amounts of rainfall. The late February storm dropped nearly 5 inches of rain over the region that primed conditions for triggering high water that followed the 4 to 7 inches of rain that fell between March 13 and 15, 2010. As flood waters began to recede, 2 to 5 inches of rain fell on March 22-23, maintaining wet conditions and elevating streamflows over the region. This was followed by another storm on March 29-30 that brought an additional 7 to 9 inches of rain, which compounded with the low moisture losses to evaporation during the cool season further elevated streamflows. The total rainfall in Rhode Island from late February to the end of March 2010 ranged from about 19 to 25 inches, which is unprecedented in the past 100year weather history.

Record total rains during late February and March resulted in peak stream stages and flows that set new periodof-record peaks at 21 of 25 streamgages in Rhode Island and southeastern Massachusetts. The highest record peaks occurred in late March-early April and generally greatly exceeded the earlier March peaks that were near or exceeded the previous record peak flows at 10 of the 25 streamgages. Following the late February rains, streamflow at two long-term streamgages, Hunt River near East Greenwich (01117000) and Wood River at Hope Valley (01118000), rose well above the 90th flow percentile, receded, then rose well above the 90th percentile again following rains in mid-March, between midand late March, and late March. Flows remained above the 90th flow percentile during this normally seasonal high flow period until about mid-April. 


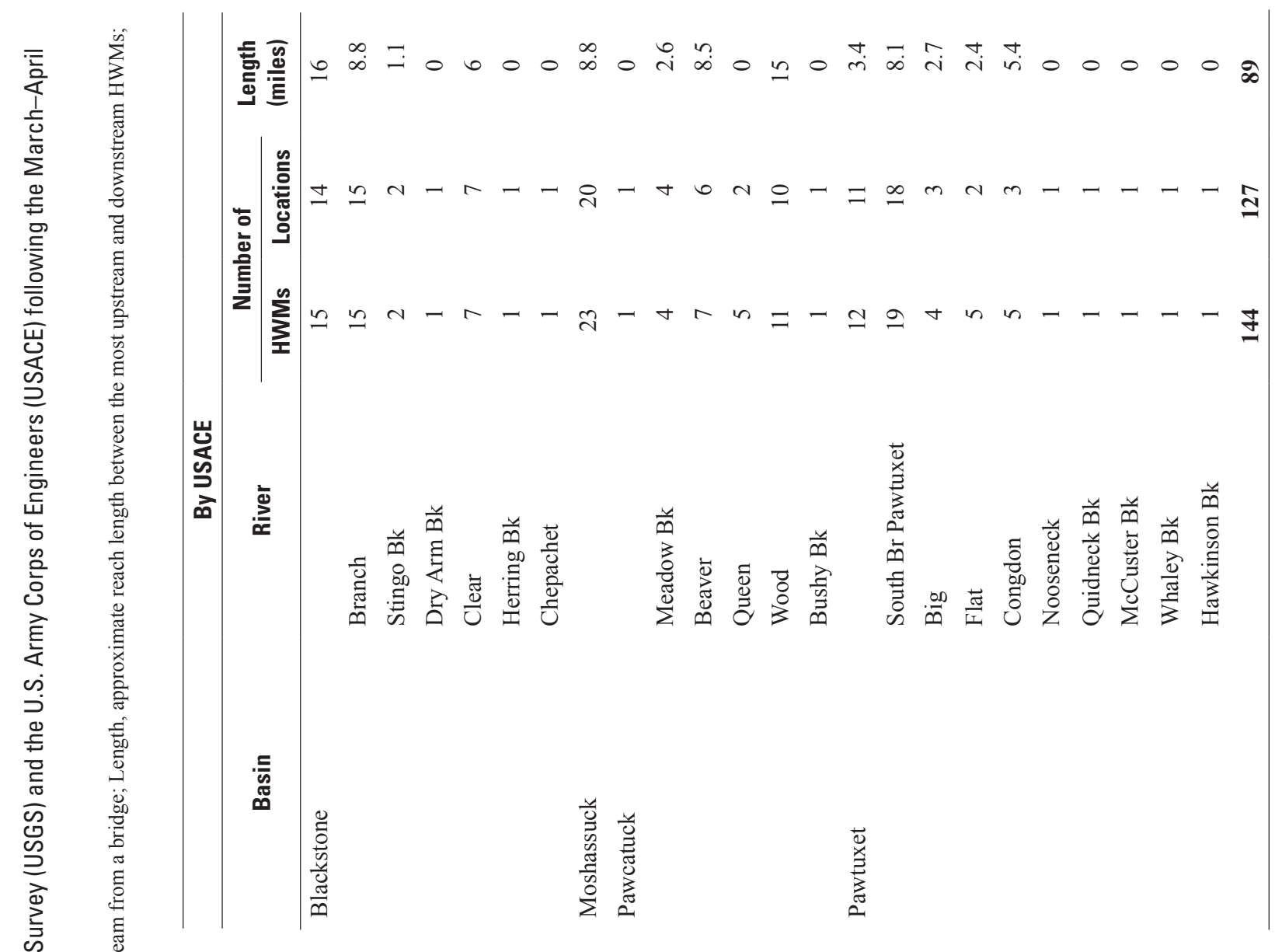

$$
\text { 譥 }
$$

(1)




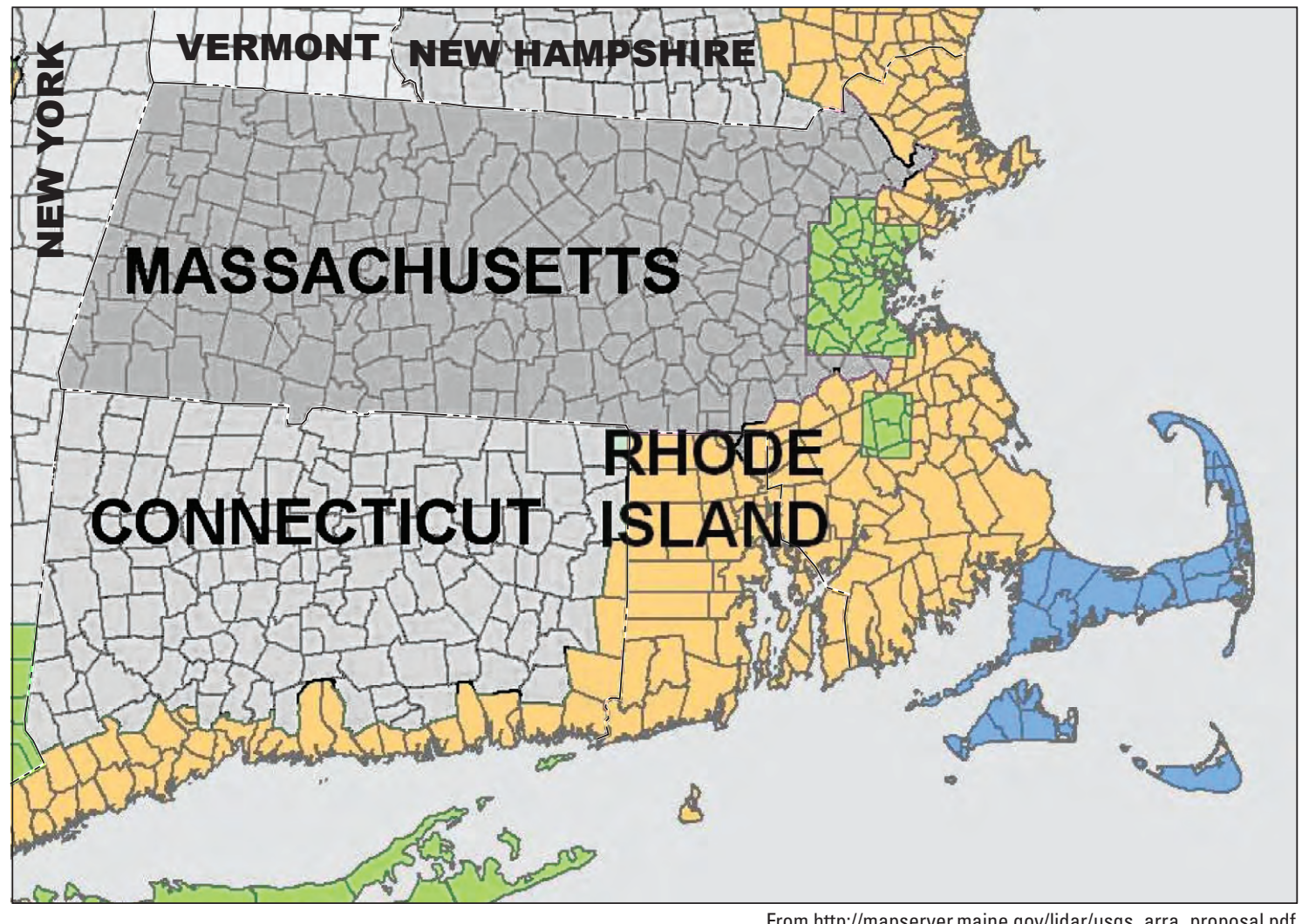

EXPLANATION

Existing LIDAR data

LIDAR data planned for aquistion in 2010-2011

FEMA planned LIDAR data aquistion in 2010-2011

Figure 7. Areas of availability of LIght Detection and Ranging (LIDAR) data and projected 2011 LIDAR data in Rhode Island and adjacent states. 
High-water marks (HWMs) were identified by the USGS from April 2-7, 2010, and by the USACE from April 3-7, 2010. The elevation of HWMs were later determined to a standard vertical datum (NAVD 88) using the Global Navigation Satellite System and survey-grade Global Positioning System (GPS) receivers along with standard optical-surveying equipment. Differential corrections to the GPS positions were made using a proprietary fixed-base station network or temporary base station. Quality-assurance GPS measurements made at 29 National Geodetic Survey bench marks with vertical datum throughout the study area yielded a vertical root mean square error of 0.09 feet.

HWMs following the March-April 2010 flood were obtained in five major river corridors including the Blackstone, Hunt, Moshassuck, Pawtuxet, and Woonasquatucket and along many of the main tributaries to these rivers. The USGS identified 276 HWMs at 137 sites. A site may have more than one HWM, typically a bridge crossing with HWMs identified on the upstream and downstream sides of the bridge. The USACE identified 144 HWMs at 127 sites. The HWMs identified by the USGS and USACE covered about 170 river miles, as determined from the upstream and downstream HWMs along a reach.

\section{Acknowledgments}

Identification of HWMs was made by USGS personnel from Water Science Centers in Massachusetts-Rhode Island (Robert Breault, Mark Nimiroski, Gene Parker, Lance Ransby, and Andy Waite), Maine (Pamela Lombard, Nicholas Stasulis, and Greg Stewart), and New York (Loyd Brook, Gary Firda, and Carolynn Szabo). HWMs identified and surveyed by USACE were supplied by Christopher Hatfield, Richard Loyd, and Gary Strangeland. Survey of HWMs was made by personnel from USGS Water Science Centers in Massachusetts-Rhode Island (Jean Campbell, Paul Friesz, Andy Massey, Timothy McCobb, Lance Ostiguy, and Andy Waite) and Ohio (Carrie Huitger, Chad Ostheimer, and Matthew Whitehead).

\section{References Cited}

Benson, M.A., and Dalrymple, Tate, 1967, General field and office procedures for indirect discharge measurements: U.S. Geological Survey Techniques of Water-Resources Investigations, book 3, chap. A1, 30 p.

FEMA-Federal Emergency Management Agency

FEMA, 2003, Guideline and specifications for flood hazard mapping partners, Appendix A: Guidance for aerial mapping and surveying, Federal Emergency Management Agency, 59 p., accessed August 6, 2010, at http://www.fema. gov/library/viewRecord.do? id $=2206$

Gesch, D.B., 2009, Analysis of Lidar elevation data for improved identification and delineation of lands vulnerable to sea-level rise: Journal of Coastal Research, SI 53, p. 49-50, available at http://topotools.cr.usgs.gov/pdfs/ jer_gesch_SI53.pdf

Northeast Regional Climate Center, 2010, New England Climate, March 2010, v. 110, no. 3, accessed July 26, 2010, at http://www.nrcc.cornell.edu/pubs/msmry_ne_2010-03.pdf

Smith, Michael; Rubin, Fay; Jacqz, Christian; White, Shane; Varney, Michael; and Ruhren, Tim, 2010, Lidar for the northeast, Maine Office of GIS, 109 p., accessed August 25, 2010, at http://mapserver.maine.gov/lidar/usgs_arra_proposal.pdf

Zarriello, P.J., and Bent, G.C., 2010, Elevation of the MarchApril 2010 flood high water in selected river reaches in central and eastern Massachusetts: U.S. Geological Survey Open File Report 2010-1315, 36 p., online at http://pubs. usgs.gov/of/2010/1315/ 
Appendix 1 


\section{Appendix 1. High-water marks identified by the U.S. Geological Survey and the U.S. Army Corps of Engineers}

Note, most of the information contained in the tables can be obtained electronically in a geographical information system format (shape file) at http://pubs.usgs.gov/ofr/2011/1029/.

- Table 1-1. High-water marks identified by the U.S. Geological Survey following the March-April 2010 flood in Rhode Island.

- Table 1-2. High-water marks identified by the U.S. Army Corps of Engineers (USACE) following the March-April 2010 flood in Rhode Island. 


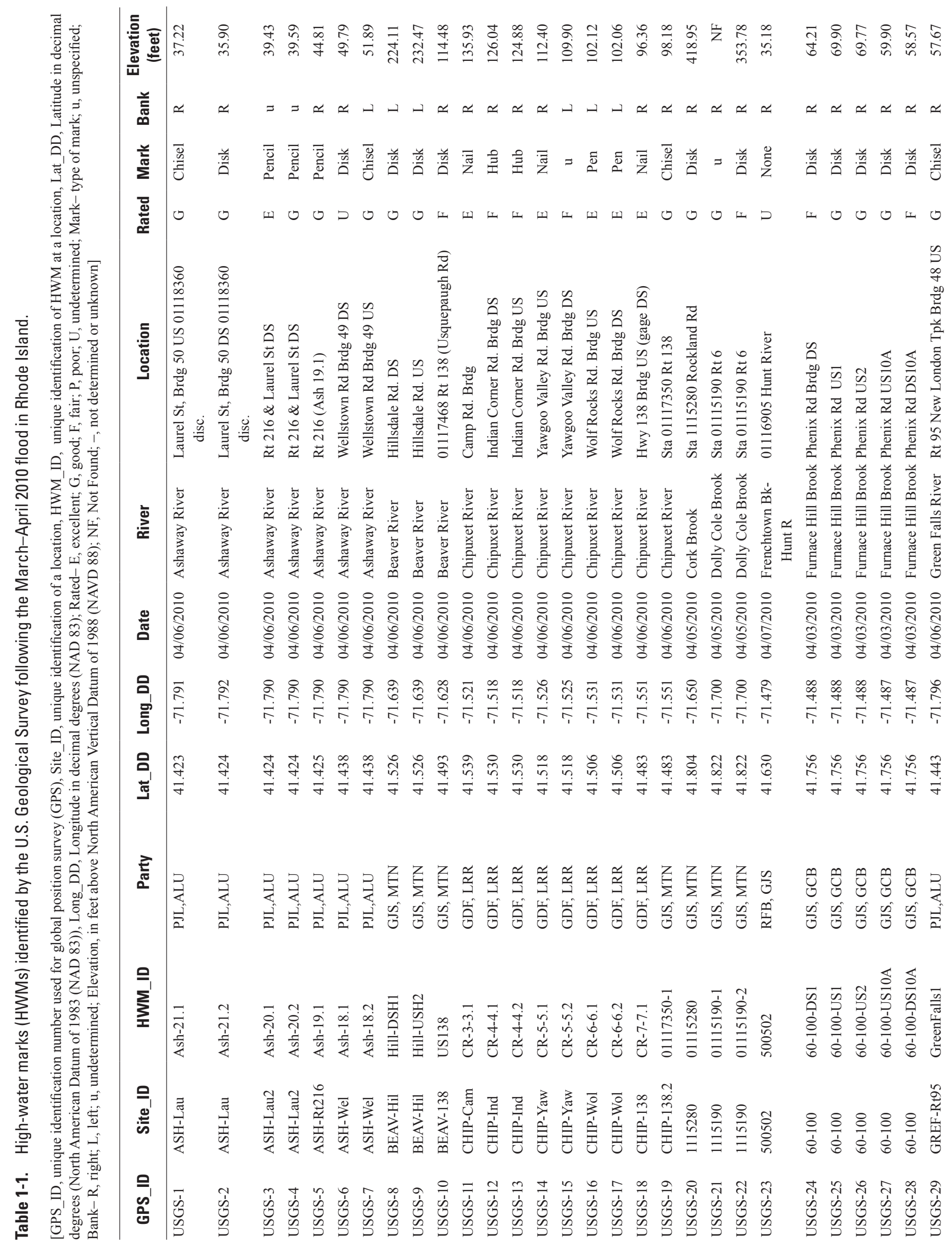




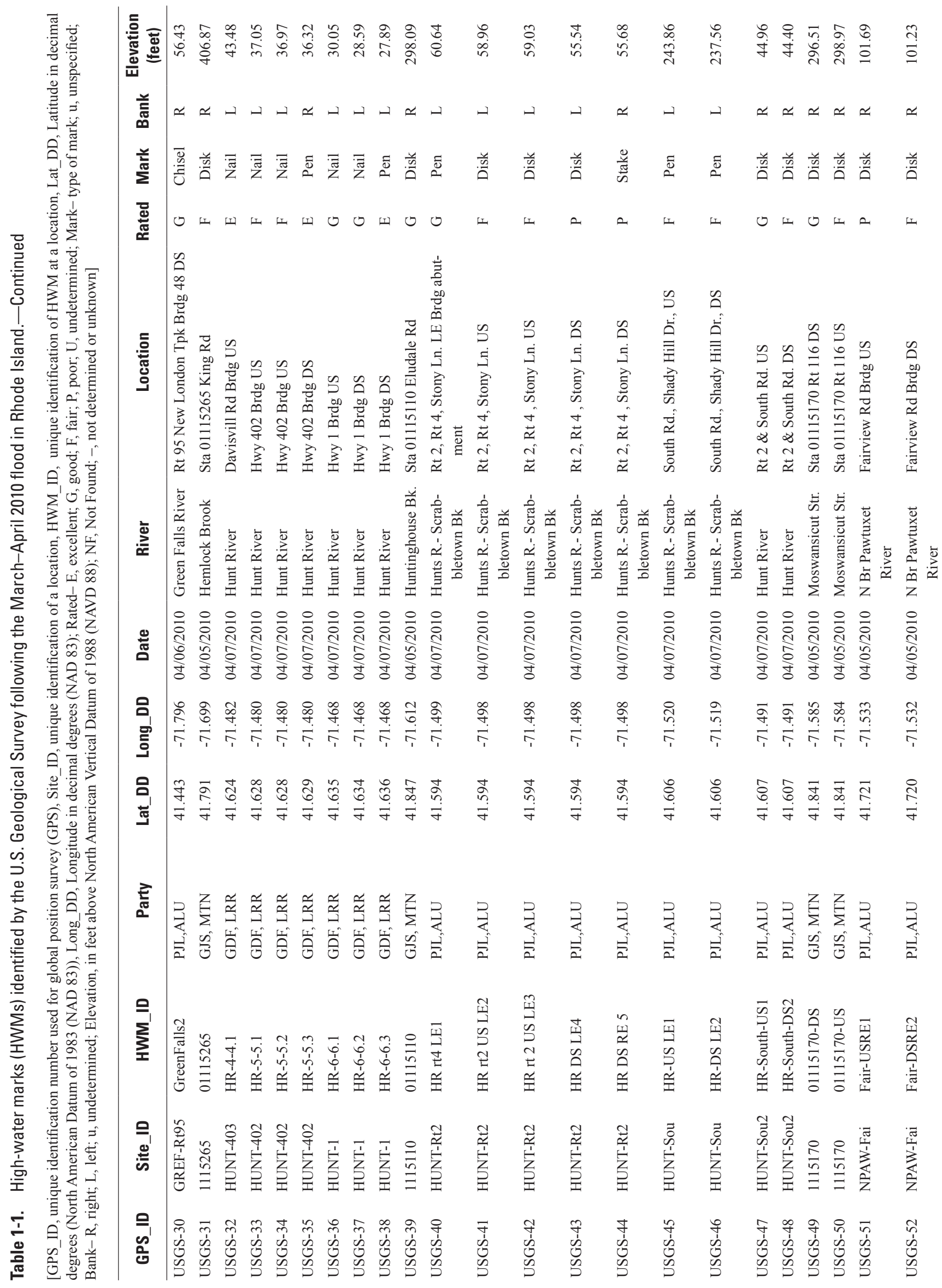




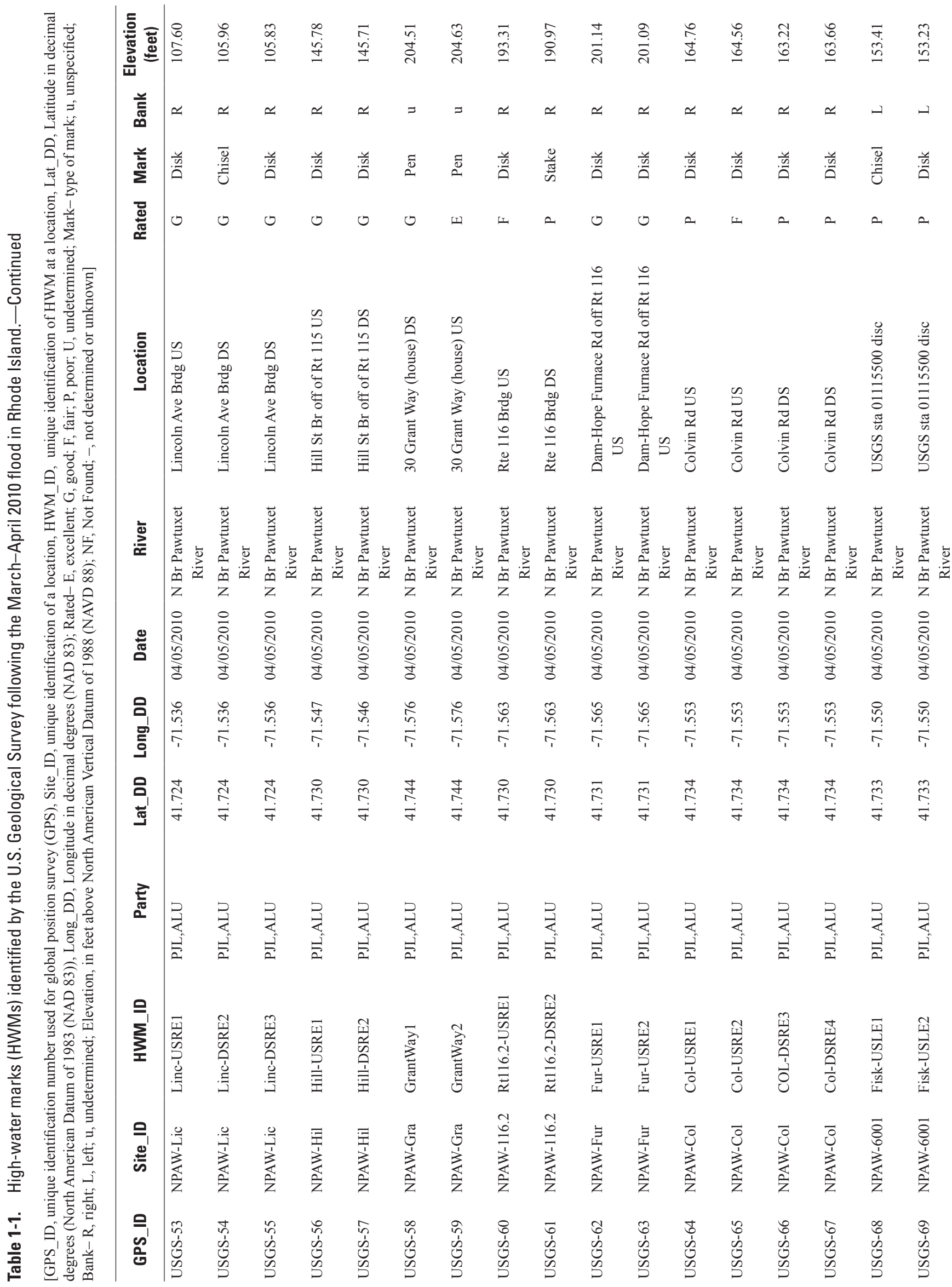




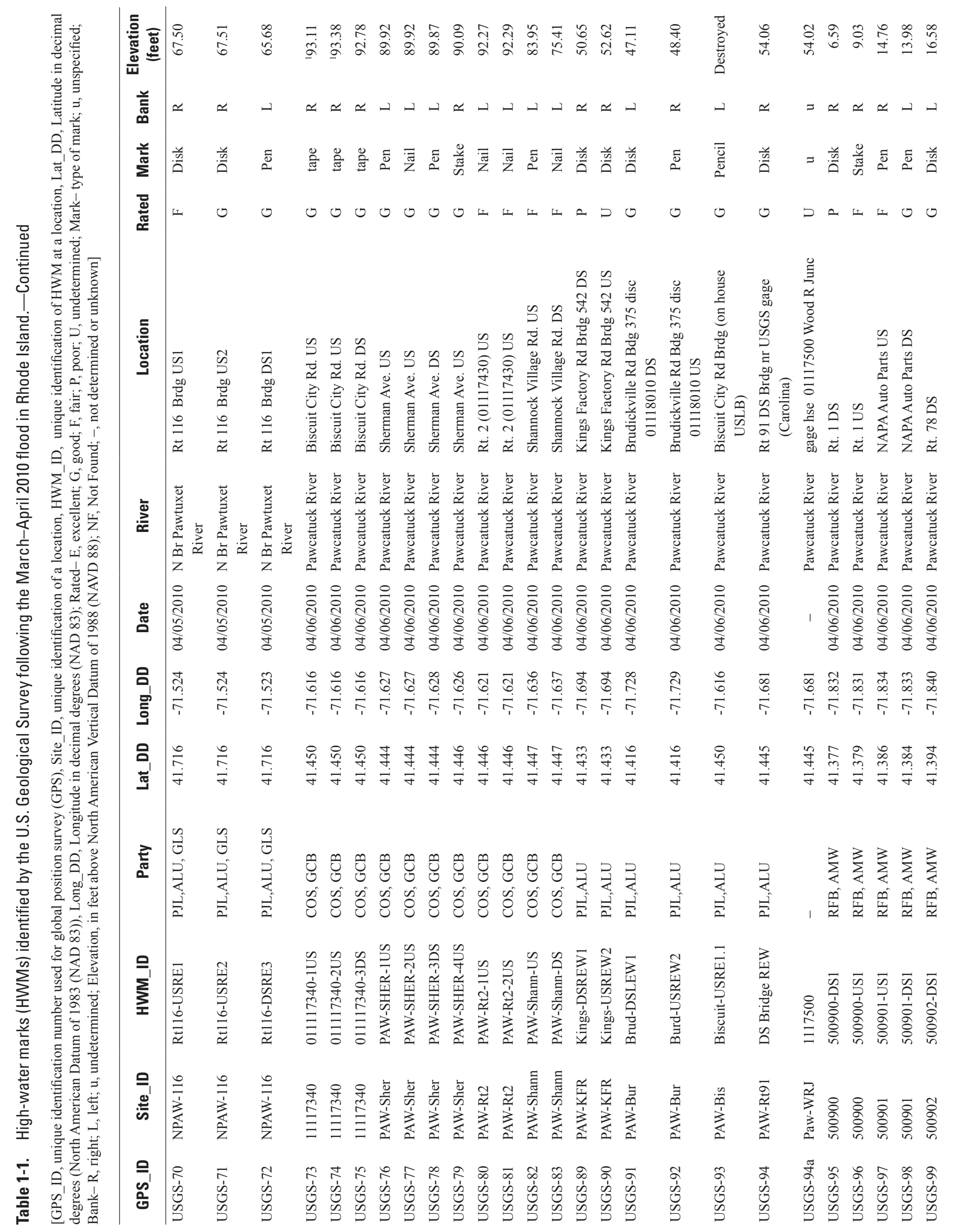




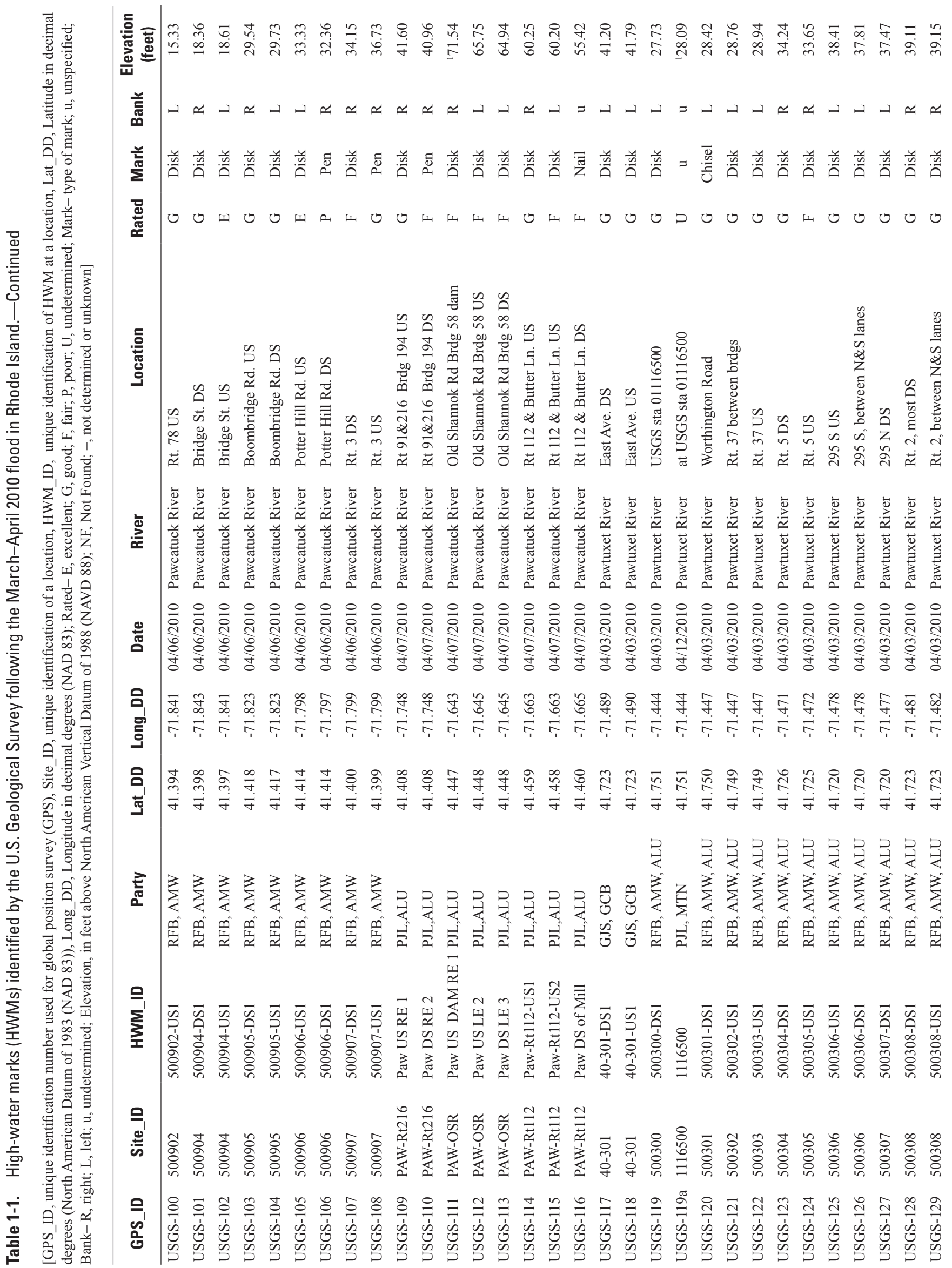




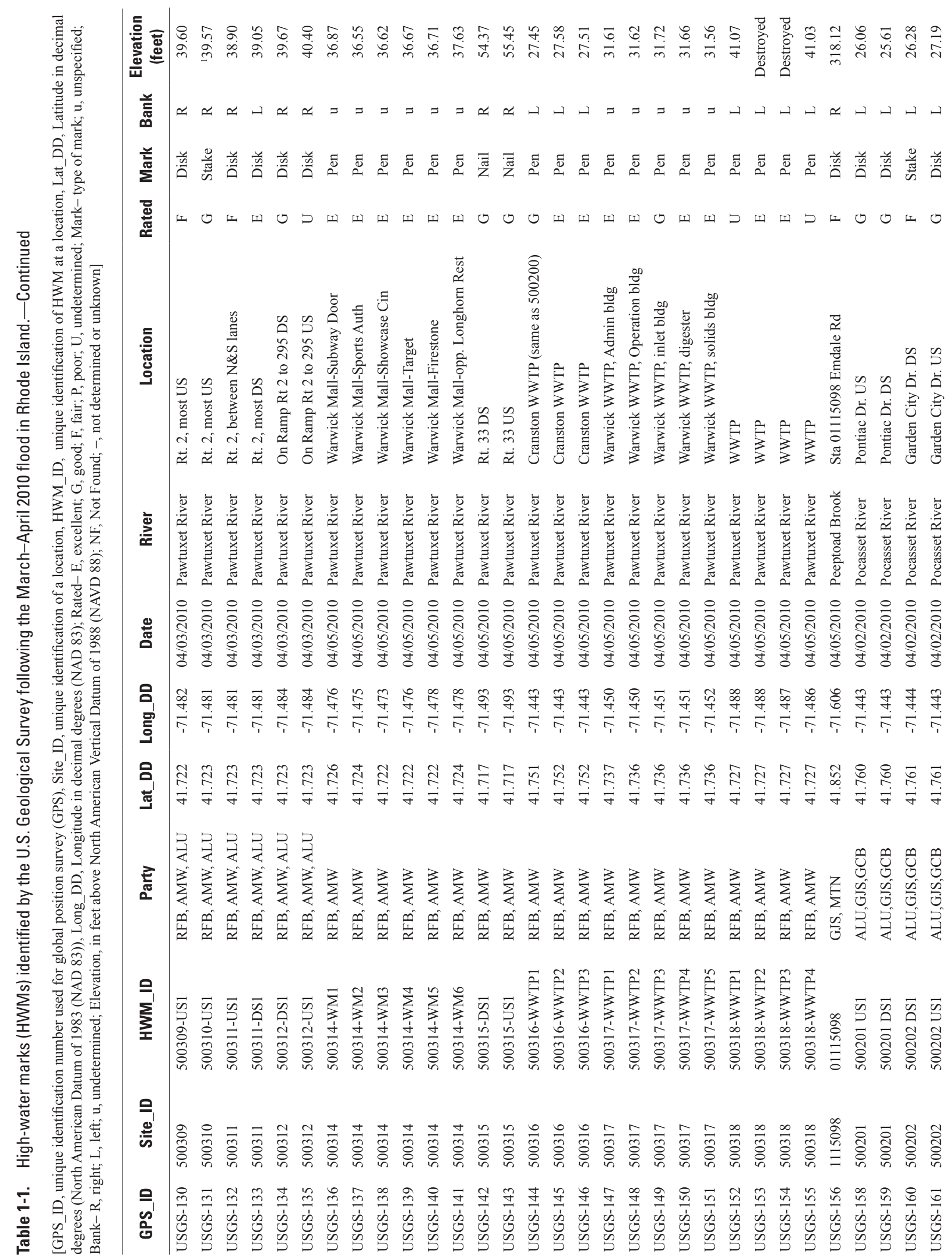




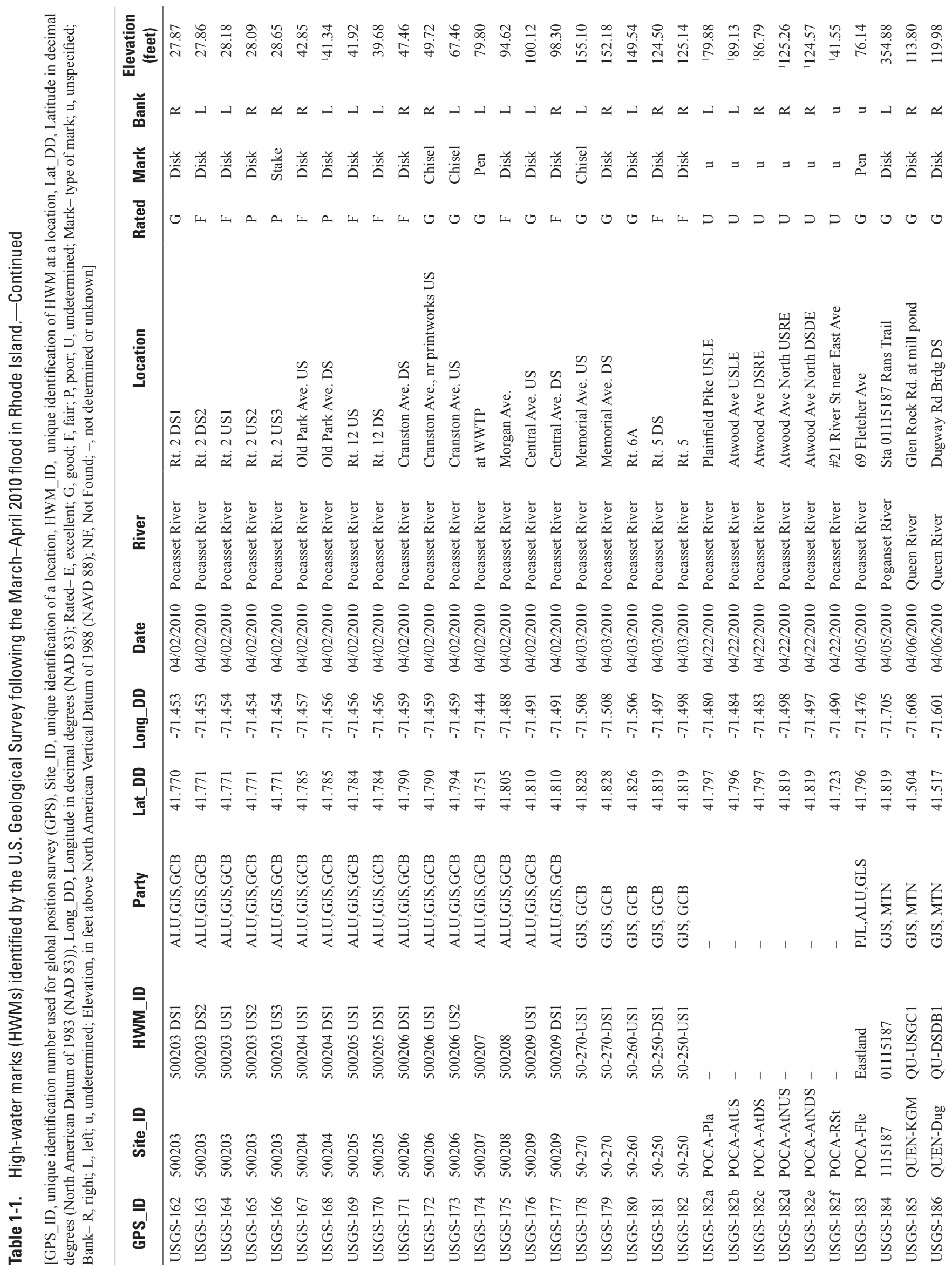




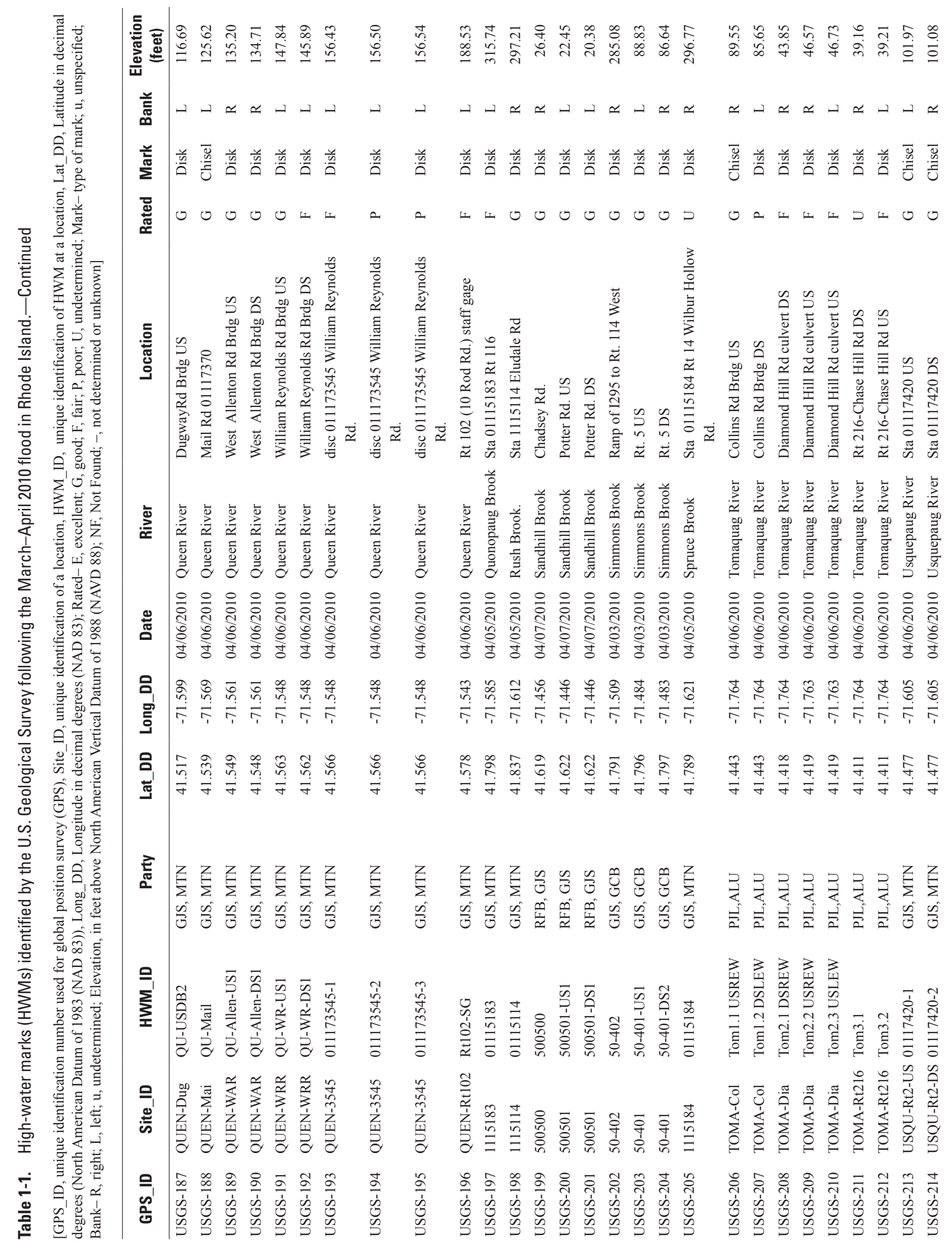




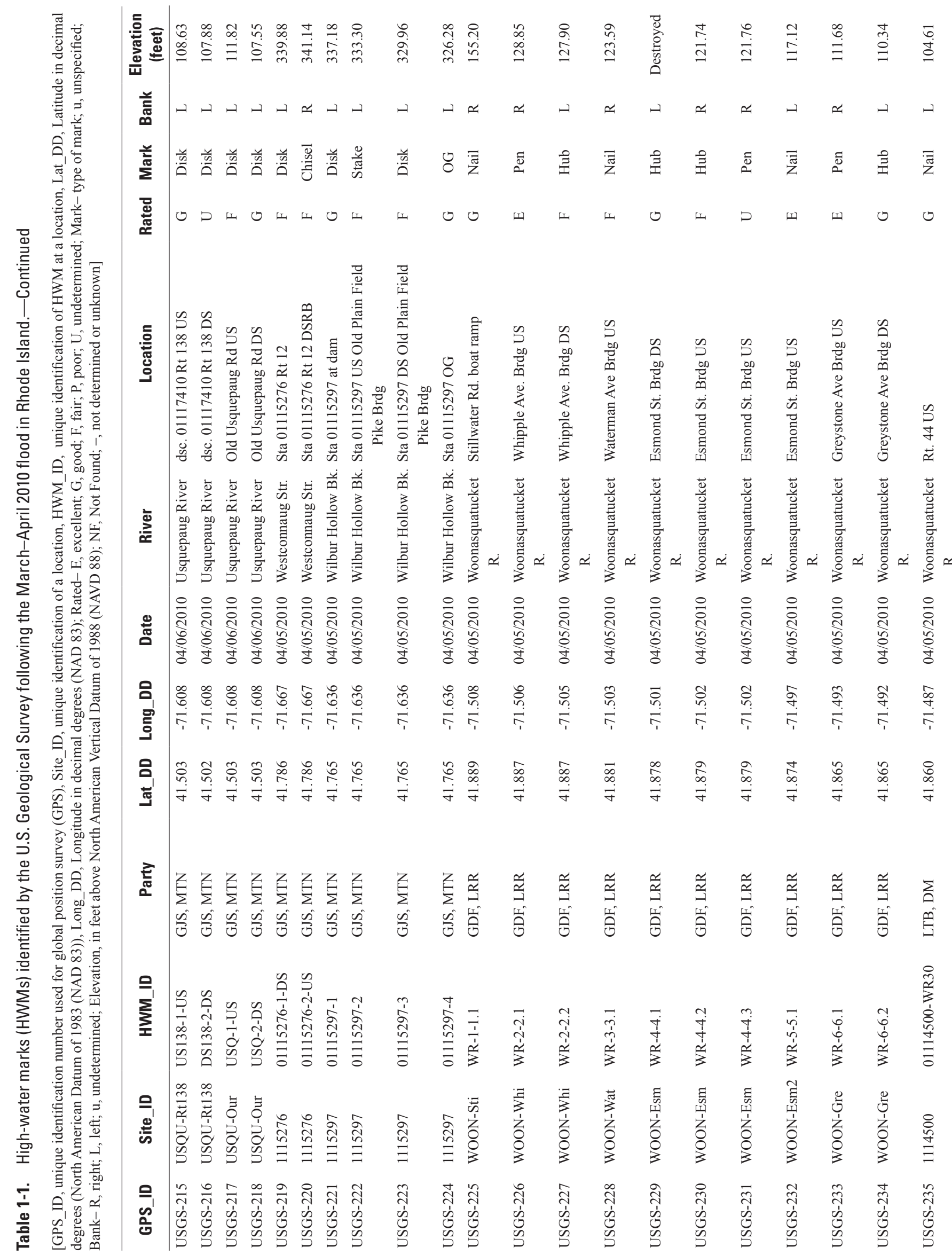




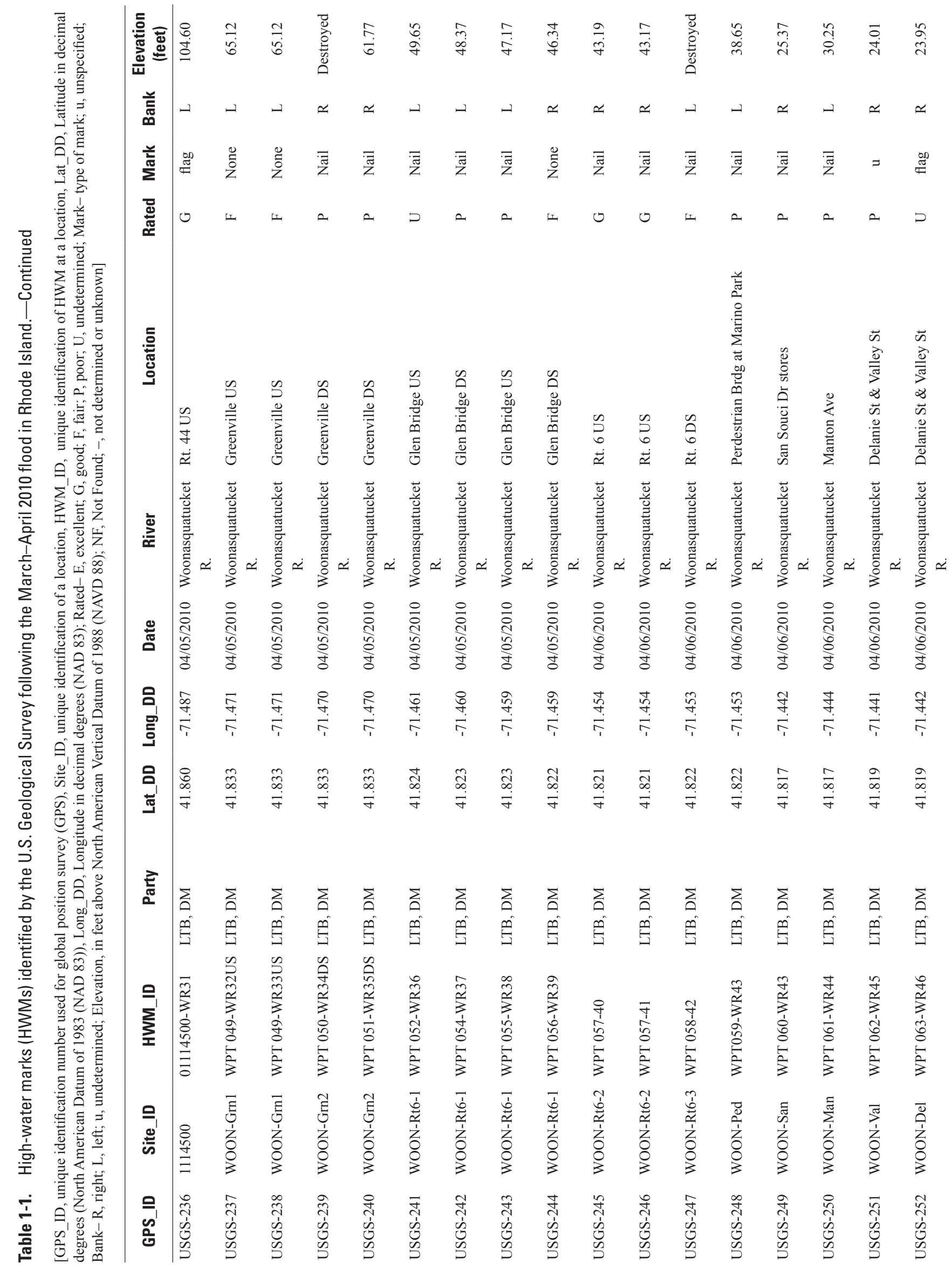




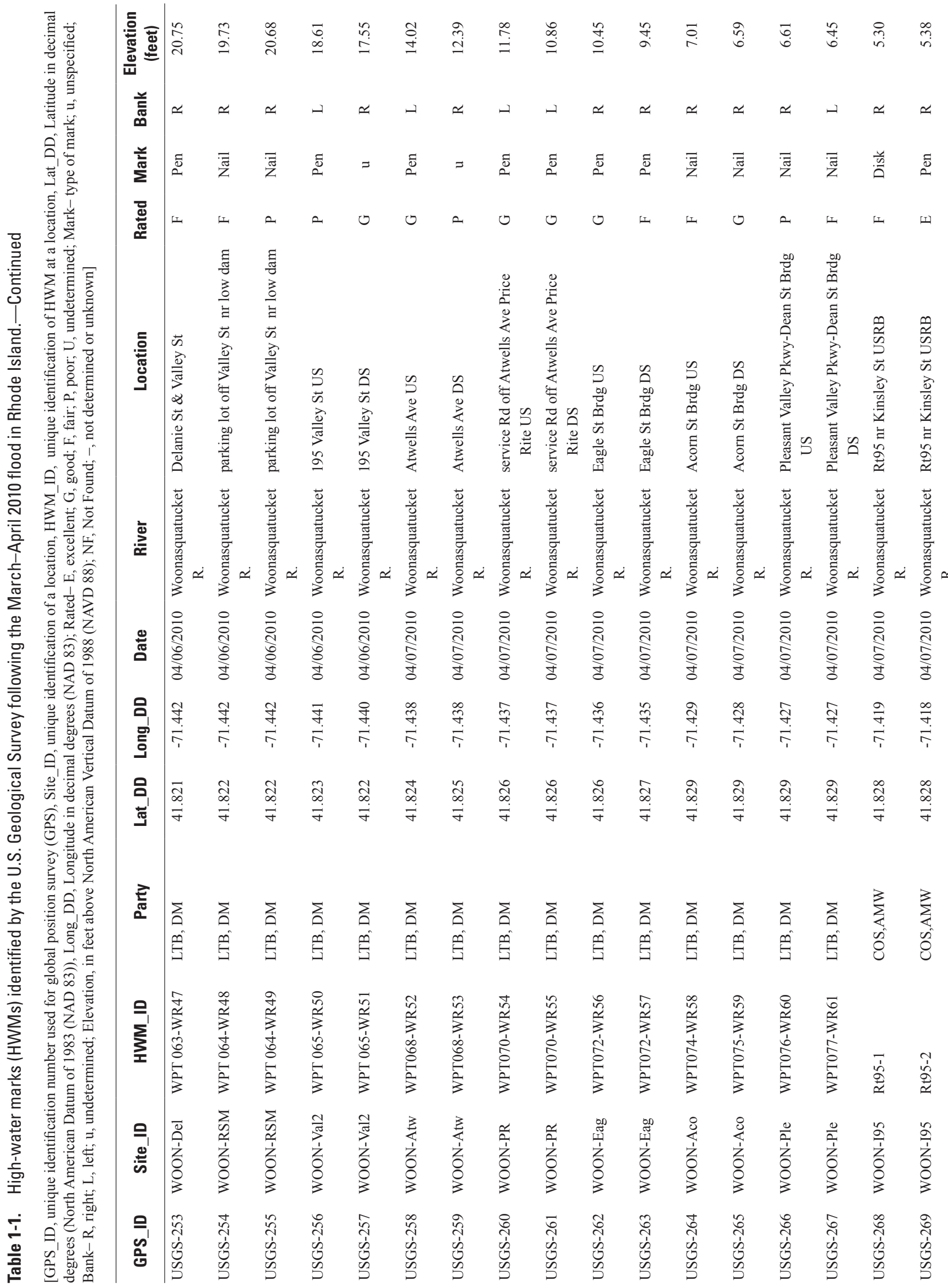




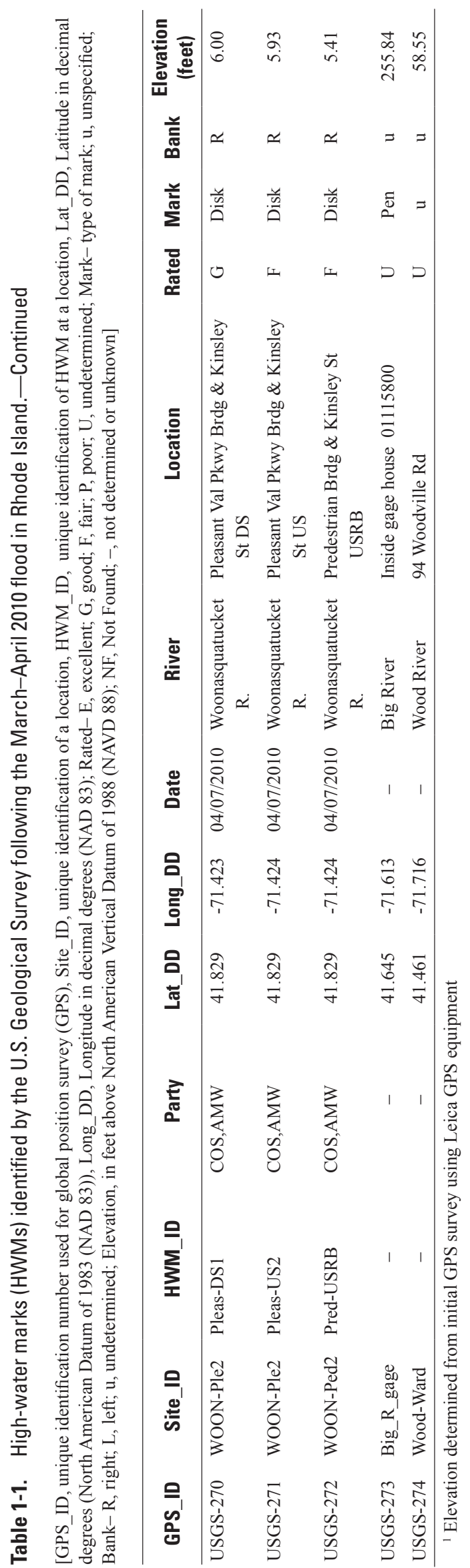


Table 1-2. High-water marks (HWMs) identified by the U.S. Army Corps of Engineers (USACE) following the March-April 2010 flood in Rhode Island.

[GPS_ID, unique identification number used for global position system (GPS) survey, HWM_ID, unique identifiation of a location, Lat_DD, Latitude in decimal degrees (North American Datum of 1983 (NAD83)), Long_DD, Longitude in decimal degrees (NAD83); DS, downstream; US, upstream; LB, left bank; RB, right bank; pt, point; -, not reported; Elevation, in feet above North American Vertical Datum of 1988 (NAVD 88); NF, Not Found; note, meaning of some of the USACE descriptor abbreviations are unknown]

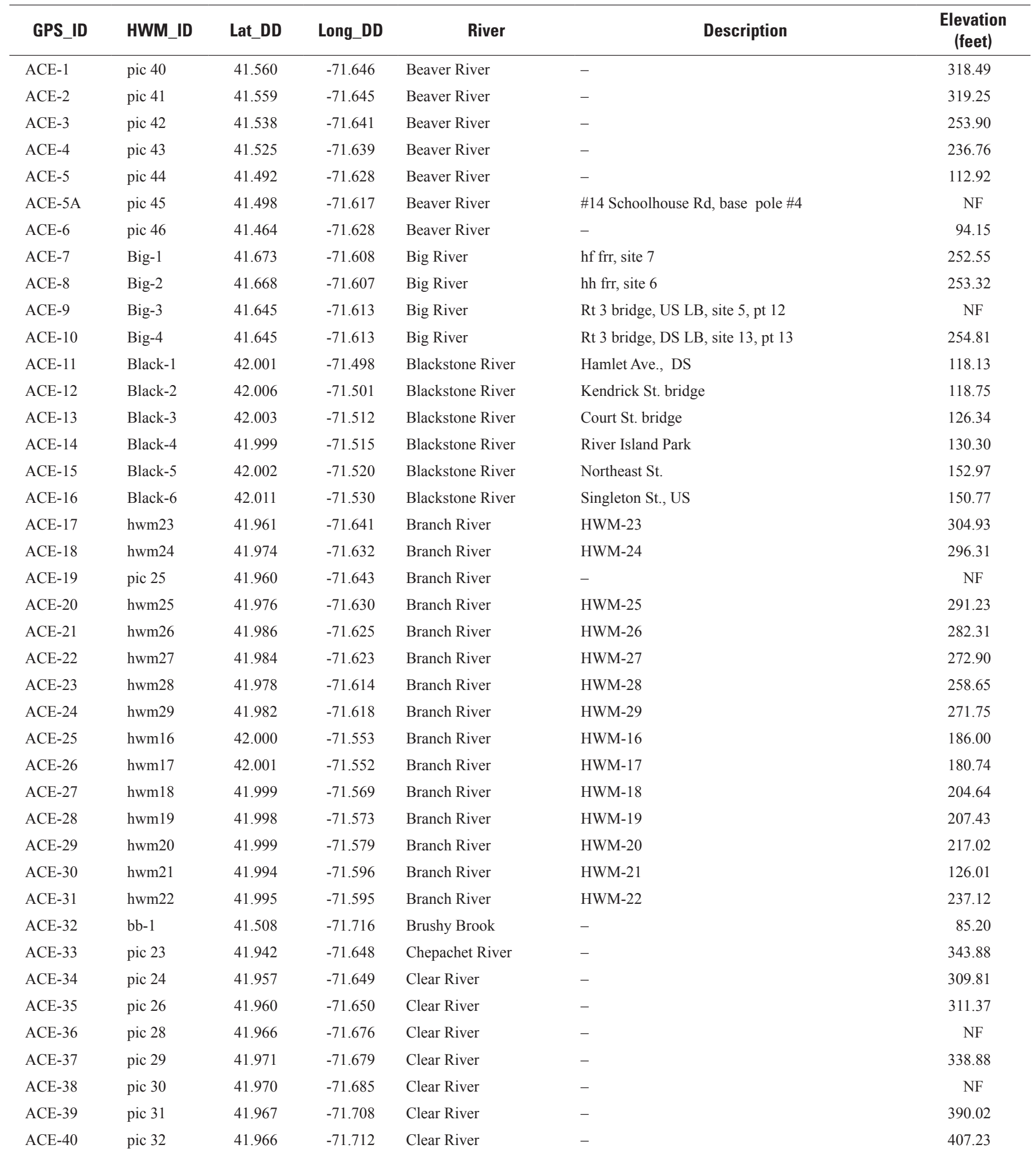


Table 1-2. High-water marks (HWMs) identified by the U.S. Army Corps of Engineers (USACE) following the March-April $2010 \mathrm{flood}$ in Rhode Island.-Continued

[GPS_ID, unique identification number used for global position system (GPS) survey, HWM_ID, unique identifiation of a location, Lat_DD, Latitude in decimal degrees (North American Datum of 1983 (NAD83)), Long_DD, Longitude in decimal degrees (NAD83); DS, downstream; US, upstream; LB, left bank; RB, right bank; pt, point; -, not reported; Elevation, in feet above North American Vertical Datum of 1988 (NAVD 88); NF, Not Found; note, meaning of some of the USACE descriptor abbreviations are unknown]

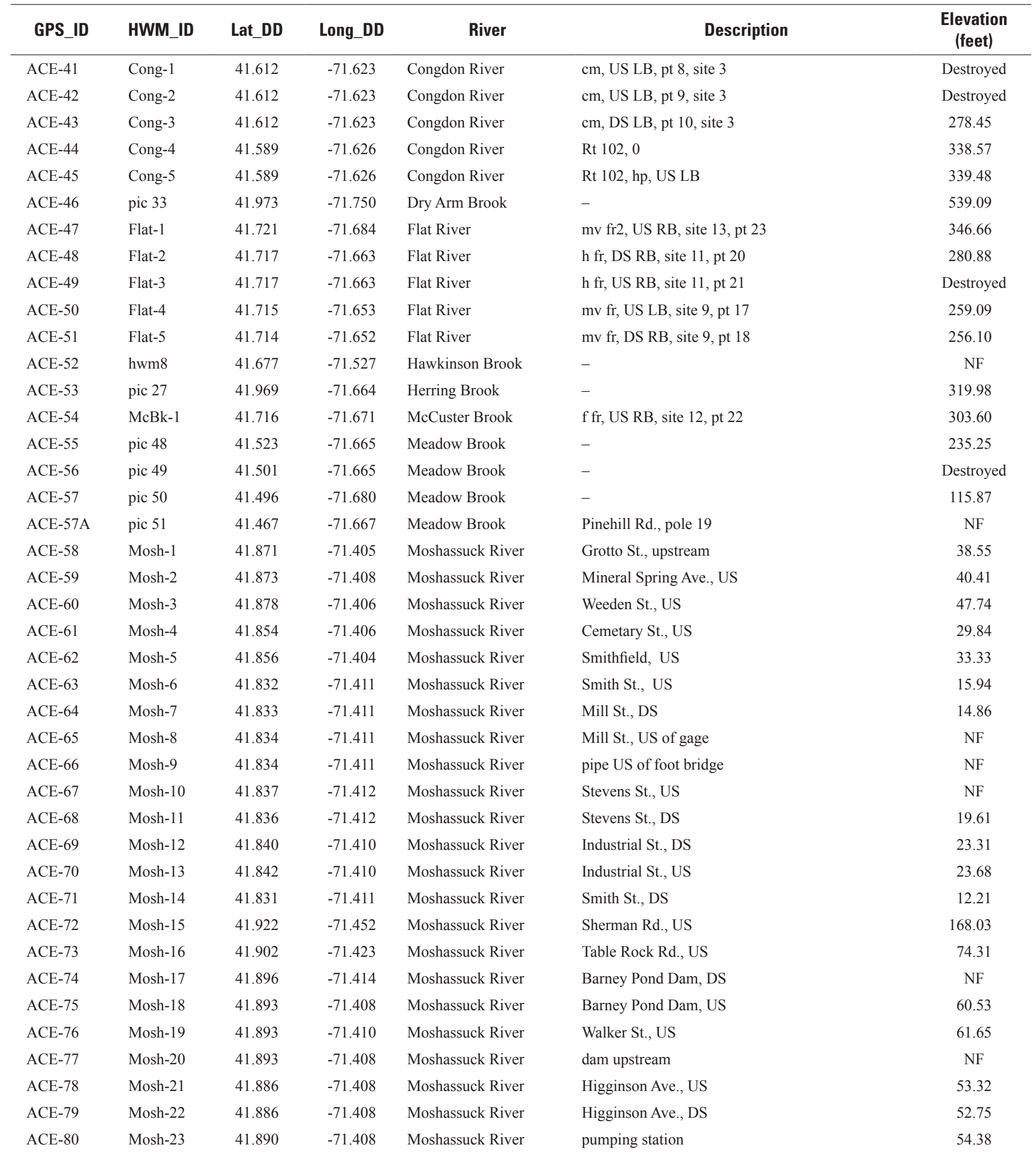


Table 1-2. High-water marks (HWMs) identified by the U.S. Army Corps of Engineers (USACE) following the March-April 2010 flood in Rhode Island.-Continued

[GPS_ID, unique identification number used for global position system (GPS) survey, HWM_ID, unique identifiation of a location, Lat_DD, Latitude in decimal degrees (North American Datum of 1983 (NAD83)), Long_DD, Longitude in decimal degrees (NAD83); DS, downstream; US, upstream; LB, left bank; RB, right bank; pt, point; -, not reported; Elevation, in feet above North American Vertical Datum of 1988 (NAVD 88); NF, Not Found; note, meaning of some of the USACE descriptor abbreviations are unknown]

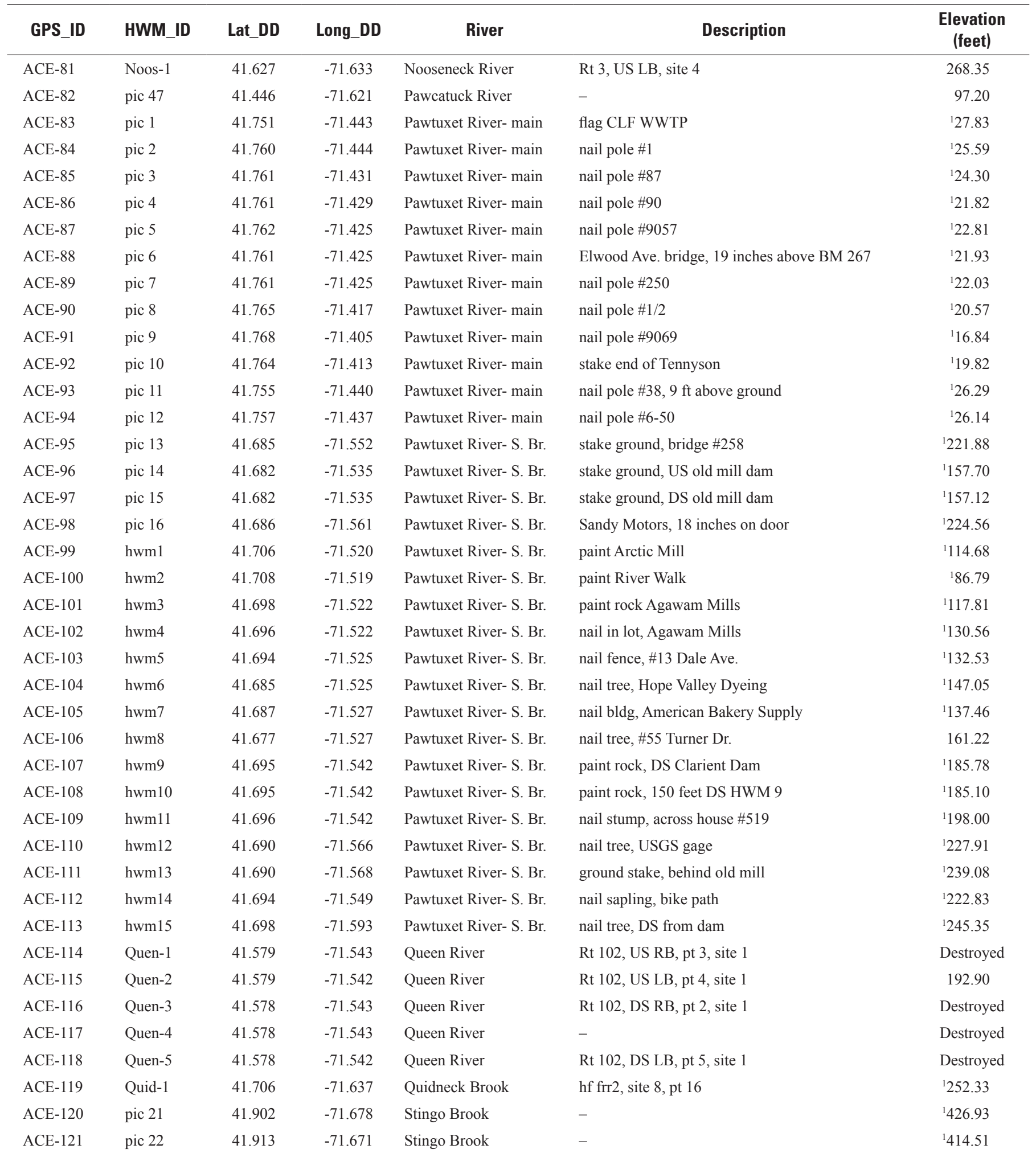


Table 1-2. High-water marks (HWMs) identified by the U.S. Army Corps of Engineers (USACE) following the March-April 2010 flood in Rhode Island.-Continued

[GPS_ID, unique identification number used for global position system (GPS) survey, HWM_ID, unique identifiation of a location, Lat_DD, Latitude in decimal degrees (North American Datum of 1983 (NAD83)), Long_DD, Longitude in decimal degrees (NAD83); DS, downstream; US, upstream; LB, left bank; RB, right bank; pt, point; -, not reported; Elevation, in feet above North American Vertical Datum of 1988 (NAVD 88); NF, Not Found; note, meaning of some of the USACE descriptor abbreviations are unknown]

\begin{tabular}{|c|c|c|c|c|c|c|}
\hline GPS_ID & HWM_ID & Lat_DD & Long_DD & River & Description & $\begin{array}{c}\text { Elevation } \\
\text { (feet) }\end{array}$ \\
\hline ACE-122 & Whal-1 & 41.719 & -71.665 & Whaley Brook & mv ut, DS RB, site 10, pt 19 & Destroyed \\
\hline ACE-124 & $w r-2$ & 41.461 & -71.718 & Wood River & nail fence & ${ }^{1} 58.91$ \\
\hline ACE-125 & $w r-3$ & 41.460 & -71.720 & Wood River & nail tree & ${ }^{1} 60.99$ \\
\hline ACE-126 & wr-4 & 41.490 & -71.715 & Wood River & nail base tree & ${ }^{1} 69.83$ \\
\hline ACE-128 & wr-6 & 41.503 & -71.716 & Wood River & paint fence & ${ }^{1} 75.37$ \\
\hline ACE-129 & $\mathrm{wr}-7$ & 41.514 & -71.705 & Wood River & paint fence & ${ }^{1} 85.88$ \\
\hline ACE-130 & wr-8 & 41.516 & -71.703 & Wood River & stake & 199.48 \\
\hline ACE-131 & wr-9 & 41.523 & -71.690 & Wood River & nail base tree & ${ }^{1} 102.05$ \\
\hline ACE-132 & wr-10 & 41.541 & -71.696 & Wood River & nail base tree & ${ }^{1} 115.21$ \\
\hline ACE-136 & Point 2 & 41.887 & -71.381 & Blackstone River & - & 34.88 \\
\hline ACE-137 & Point 3 & 41.888 & -71.381 & Blackstone River & - & 41.90 \\
\hline ACE-138 & Point 4 & 41.915 & -71.405 & Blackstone River & - & NF \\
\hline ACE-139 & Point 5 & 41.925 & -71.428 & Blackstone River & - & 70.65 \\
\hline ACE-140 & Point 6 & 41.930 & -71.430 & Blackstone River & - & 71.08 \\
\hline ACE-141 & Point 7 & 41.927 & -71.428 & Blackstone River & - & 71.03 \\
\hline ACE-142 & Point 8 & 41.952 & -71.452 & Blackstone River & - & $\mathrm{NF}$ \\
\hline
\end{tabular}

\footnotetext{
${ }^{1}$ Elevation determined by USACE GPS survey using Leica GPS equipment .
} 
For additional information, write to:

Director

U.S. Geological Survey

Massachusetts Water Science Center

10 Bearfoot Road

Northborough, MA 01532

or visit our Web site at:

http://ma.water.usgs.gov/

Document prepared by the Pembroke and West Trenton Publishing Service Centers 


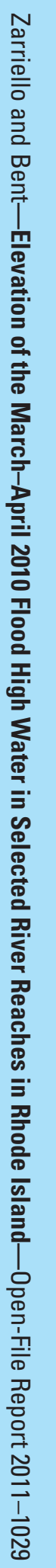

Printed on recycled paper 